\title{
Monitoring and analysis of the bending behaviour of discrete piles used to stabilise a railway embankment
}

\author{
J. A. SMETHURST* and W. POWRIE*
}

\begin{abstract}
Discrete piles are used to stabilise infrastructure slopes, especially where there is insufficient additional land to allow construction of large toe berms or regrading of the slope. Compared with more conventional structures such as retaining walls, there are few field data on how discrete piles typically bend and displace under slope loading. This paper presents the results from monitoring a number of discrete piles used to stabilise a railway embankment at Hildenborough, Kent, UK. Bending deflections deduced from strain gauges are compared with the displacements and rotations measured by inclinometer tubes cast into the piles. Four years after pile installation, the piles were bending downslope over their lower halves, with little bending measured in the upper sections. Regrading of the rockfill piling platform shortly after pile construction caused some of the pile loading, with further loading caused by the continued tendency for slope movement. Analysis of the piles using a simple elastic analysis gives bending moments and displacements close to those measured.
\end{abstract}

KEYWORDS: embankments; field instrumentation; ground movements; monitoring; piles; slopes
On utilise des pieux discrets pour stabiliser les pentes d'infrastructures, notamment lorsqu'on ne dispose pas de terrains supplémentaires suffisants pour permettre la construction de bermes en aval ou la modification du profil de la pente. Par rapport à des structures de type plus traditionnel, par exemple les murs de soutènement, on dispose de bien peu de données sur le terrain permettant de savoir comment les pieux discrets ont tendance à se plier et à se déplacer sous les forces des pentes. La présente communication présente les résultats d'examens effectués sur un certain nombre de pieux discrets servant à stabiliser un talus de chemin de fer situé à Hildenborough, dans le Kent, au Royaume-Uni. On compare des flèches par pliage déduites des relevés sur les jauges de contrainte et les déplacements et rotations mesurés avec des inclinomètres moulés dans les pieux. Quatre ans après avoir été mis en place, les pieux présentaient une inclinaison vers le bas de la pente, sur leur moitié inférieure, la flèche mesurée sur leur section supérieure étant beaucoup moins prononcée. La modification du profil de la plate-forme de l'empilement sur l'enrochement, peu de temps après la construction des pieux, est à l'origine de certaines charges sur les pieux, ces derniers étant également soumis à d'autres charges dues à la tendance permanente au déplacement des pentes. L'analyse des pieux au moyen d'une simple analyse élastique permet d'obtenir des moments de flexion et des déplacements proches de ceux qui sont mesurés.

\section{INTRODUCTION}

Discrete piles are often used to stabilise infrastructure slopes, especially where there is insufficient additional land to allow construction of large toe berms or complete regrading of the slope. With a long life expectancy, they provide a long-term solution to slope instability, particularly where the consequences of slope failure (such as on a railway embankment) may be severe.

Where discrete piles are used to pin a slipping layer to an underlying unyielding stratum, the directions of relative soil/ pile motion and hence the forces that will act on the piles are reasonably clear. The underlying unyielding stratum will hold the lower portions of the piles in place, while the upper parts of the piles will resist the motion of the slipping layer. The limiting conditions are then either soil flow around the piles within the failing mass, or formation of a plastic hinge in the pile near the interface between the underlying unyielding stratum and the slipping soil.

In most infrastructure slope applications, there will not be any obvious underlying unyielding stratum. Even if there is a suspected pre-existing failure surface, it is likely to be in material whose properties will probably change only gradually

Manuscript received 22 May 2006; revised manuscript accepted 27 June 2007.

Discussion on this paper closes on 1 April 2008, for further details see p. ii.

* School of Civil Engineering and the Environment, University of Southampton, UK with depth. In this case, the directions of relative pile/soil motion are not as clear, the well-defined limiting conditions described above do not necessarily apply, and the directions of the soil/pile interface pressures require further consideration.

It should be possible, by means of a conventional limit equilibrium analysis, to identify the critical failure mechanism for the slope (Fig. 1(a)). The soil deformations associated with this mechanism, assuming rigid-plastic soil behaviour, are indicated schematically in Fig. 1(b) together with the corresponding pile displacements assuming that the pile is relatively stiff in bending. The pressures exerted on the pile by the soil may be explored by considering the resulting relative soil-pile movements. Downslope pressures are exerted on the pile by the soil where the slope tends to move downslope relative to the pile, that is, over most of the putative slipping mass and near the pile toe. The pile is supported by the soil where the pile moves downslope relative to the soil, so that the resulting pressure on the pile is upslope. The pile is likely to experience upslope pressures over most of its length below the putative slip surface, but also near the top as a result of the pile bending stiffness forcing it downslope relative to the soil at this point. A qualitative indication of the loading likely to be experienced by discrete piles used for infrastructure slope stabilisation, neglecting the effects of differential pre-failure soil stiffness and pile bending, is shown in Fig. 1(c).

Compared with more conventional structures such as retaining walls, there are relatively few field data on how discrete piles typically bend and displace under loads imposed by the slope. Measurements of real pile behaviour are 


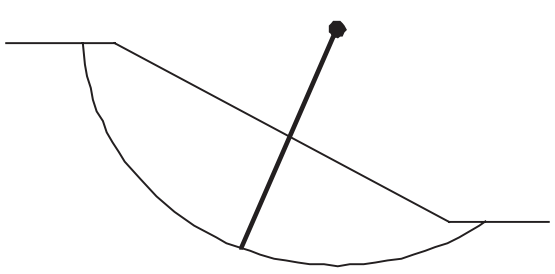

(a)

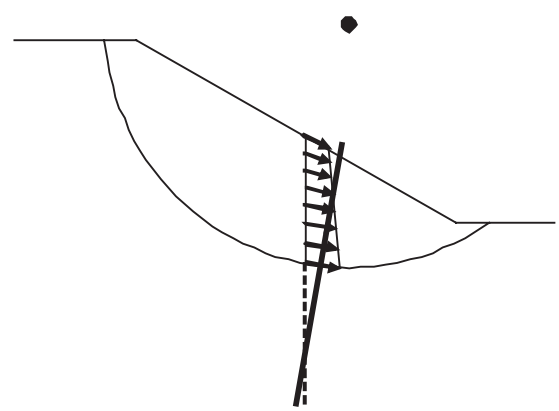

(b)

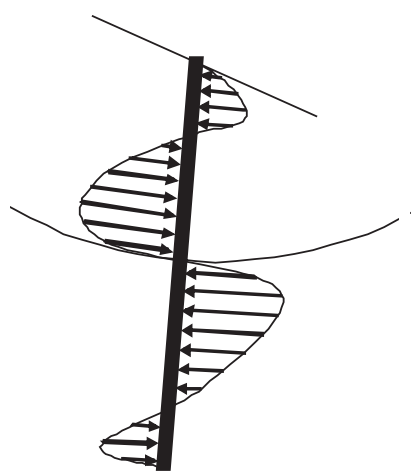

(c)

Fig. 1. (a) Critical failure mechanism determined from limit equilibrium slope stability analysis; (b) soil deformations (assuming rigid-plastic behaviour) and likely pile displacement; (c) schematic of qualitative pile pressure likely to be experienced by discrete piles used for infrastructure slope stabilisation

required both to develop an understanding of real mechanisms of behaviour and to facilitate a move towards the regular use of elastic and finite element analyses in the design of discrete piles for infrastructure slope stabilisation. In this paper, the results from monitoring discrete piles used to stabilise a railway embankment at Hildenborough, Kent, UK, are presented. The pile displacements and rotations measured by inclinometer tubes cast into the piles are compared with the pile bending determined from pairs of embedded strain gauges. Simple elastic analyses are carried out to demonstrate that the measured pile behaviour can reasonably be represented using an elastic analysis in which the model pile is loaded by movement of the slope.

\section{THE INSTRUMENTATION SITE}

The instrumented discrete piles form part of a scheme to stabilise a railway embankment, about $8 \mathrm{~m}$ high and comprising tipped Weald Clay, at Hildenborough, Kent, UK (OS grid reference TQ556485). Remediation of the embankment was carried out to solve long-term serviceability problems, including excessive side slope displacements and track settlements. Stability calculations carried out after an initial site investigation showed the north slopes of the embankment to be close to failure. Mature vegetation was removed from the embankment slopes in May 2000 to carry out a further investigation of the embankment with a view to constructing remedial works. Removal of the vegetation may have contributed to a number of shallow rotational slope failures during a period of prolonged rainfall in October and November 2000. The instrumented section of the slope remained stable, but an adjacent section did fail with a slip approximately $2 \mathrm{~m}$ below the original slope surface. A $3.5 \mathrm{~m}$ high rockfill berm was constructed at the toe of the embankment, and 200 piles were installed along two lengths of the embankment to increase the factor of safety (on moment stability) to the required value of $1 \cdot 3$. The extent of the remedial works is shown in plan in Fig. 2.

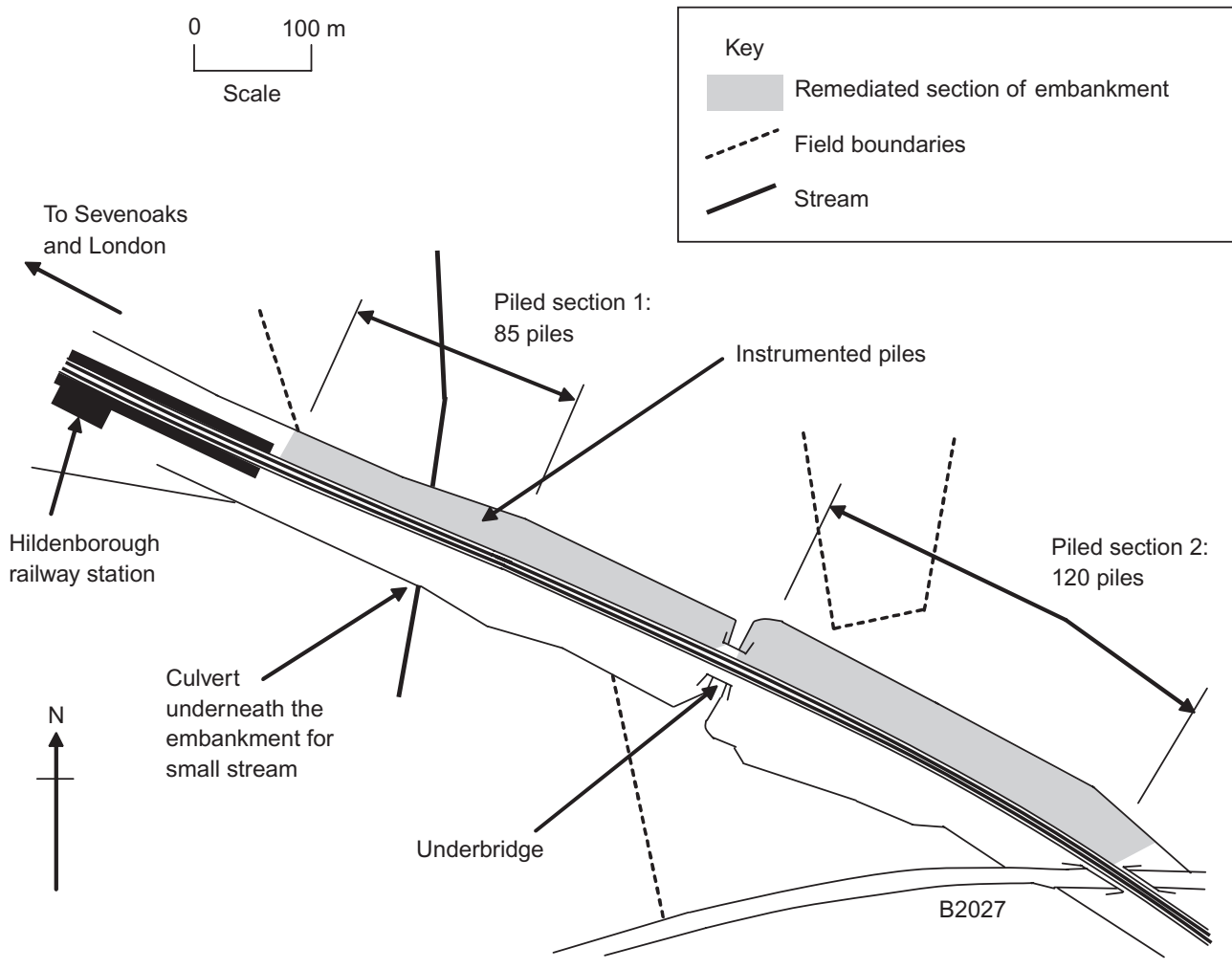

Fig. 2. Location sketch showing remediated sections of embankment 
The site is underlain by the Weald Clay, in the Tonbridge area, to a depth of about $250 \mathrm{~m}$ (Gallois \& Edmunds, 1965). The deposit is dark grey stiff thinly laminated closely fissured clay, with occasional clay ironstones. The top metre is weathered, as evidenced by a change in colour to mottled brown and yellow. The embankment fill material is entirely weathered. The soil strength parameters used in design, which are based on data from the site investigation and associated triaxial tests, are given in Table 1.

\section{THE INSTRUMENTED EMBANKMENT SECTION}

The piles at the instrumented section are $10 \mathrm{~m}$ long, $0.6 \mathrm{~m}$ diameter bored concrete piles constructed at a spacing of $2.4 \mathrm{~m}$ (equivalent to 4 pile diameters). The pile bores were drilled using a continuous flight auger rig and filled with concrete before the cages were installed. Each pile contains six T25 reinforcement bars over their full length, and six T32 bars over the bottom $7 \mathrm{~m}$, giving an estimated ultimate bending moment capacity of $250 \mathrm{kNm}$ over the top $3 \mathrm{~m}$, and $520 \mathrm{kN} \mathrm{m}$ over the bottom part of the pile.

Figure 3(a) shows the instrumented pile group shortly after installation in April 2001. On 19-20 April 2001 (days 22 and 23 after pile construction), the granular rockfill material was regraded into a two-stage slope (Fig. 3(b)). The final regrading profile included a small horizontal platform downslope of piles $\mathrm{B}$ and $\mathrm{C}$ (visible in Fig. 3(b)). Fig. 4 shows the embankment profile geometry, both shortly after pile construction and after the construction platform had been regraded.

Strain gauges were installed in three adjacent piles to measure the bending moments induced in the pile by slope movements. Inclinometer tubes were installed both inside the strain-gauged piles and in the slope midway between each pair of instrumented piles to measure any difference in the movement of the piles and movement of the soil midway between the piles (Fig. 5).

Twelve Slope Indicator vibrating-wire strain gauges in six pairs were cast into each of the three instrumented piles. The strain gauges were installed by gluing them to small, flat surfaces machined into the side of the reinforcement bars making up the pile cage, in pairs spaced at $1.6 \mathrm{~m}$ centres down the pile (Fig. 6). The strain gauges were datalogged to obtain a continuous record of their output.

Pile C also contains twelve Gage Technique vibrating-wire concrete embedment strain gauges, installed to compare their performance with those attached to the reinforcement cage. The embedment gauges measure the strain within the concrete, and were supported during pile construction by steel holding bars spanning between adjacent pile reinforcement bars. To minimise damage to the embedment gauges during installation of the cage into the concrete-filled pile bore, additional steel holding bars were attached about $200 \mathrm{~mm}$ below the base of each gauge.

The $100 \mathrm{~mm}$ diameter holes for the inclinometer tubes installed midway between the piles were bored using a shell and auger rig on days 3 and 4 after pile construction. As

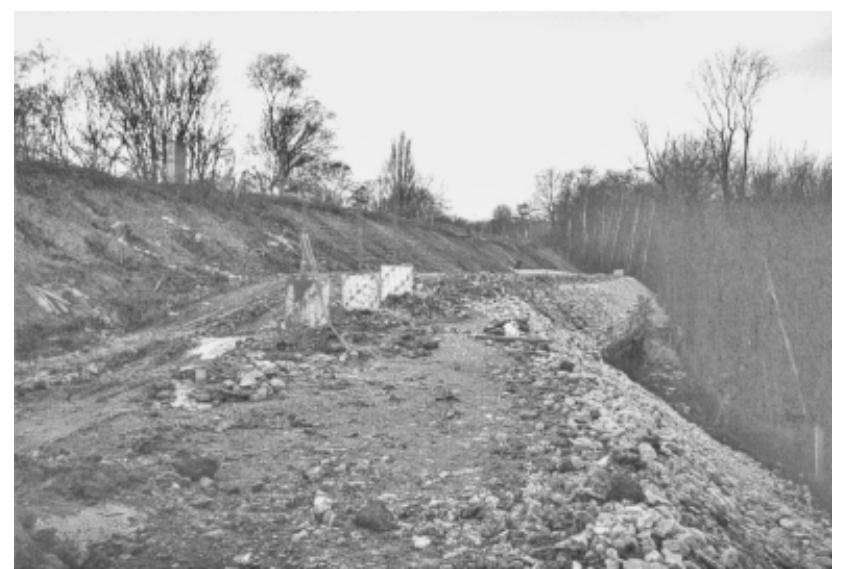

(a)

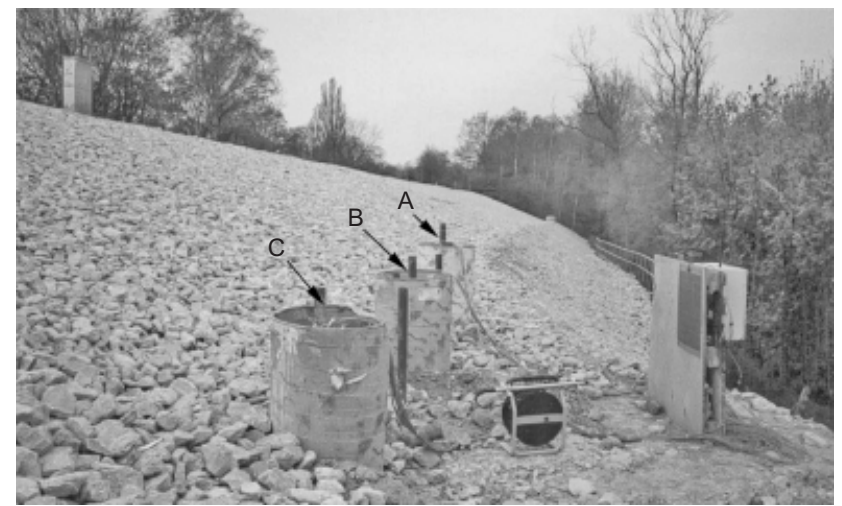

(b)

Fig. 3. Instrumented section of embankment at Hildenborough: (a) shortly after pile construction; (b) after berm had been regraded to create a two-stage slope

this was unable to drill through the rockfill material used to construct the berm, the rockfill in the zone between the piles was excavated out and replaced with HA Type 1A granular fill material on day 2 after pile construction, and the holes were then augered through the Type 1A material. On completion, the inclinometer tubes were grouted in using a cement/bentonite grout.

\section{PILE DESIGN}

The piles were designed using a limit equilibrium slope stability analysis to assess the factor of safety (defined as the ratio restoring moments/destabilising moments) of the regraded slope. The critical circular arc failure surface was found to pass through the proposed pile location at a depth of $4 \mathrm{~m}$ below the slope surface, and is shown in Fig. 4(b). A point force of $60 \mathrm{kN}$ was applied in the analysis at twothirds the depth of the failing mass to increase the factor of safety to $1 \cdot 3$. The pile length and design bending moment distribution were determined using a limit equilibrium calcu-

Table 1. Design soil parameters

\begin{tabular}{l|c|c|c}
\hline Soil type & $\begin{array}{c}\text { Unit weight, } \\
\gamma: \mathrm{kN} / \mathrm{m}^{3}\end{array}$ & $\begin{array}{c}\text { Friction angle, } \\
\phi^{\prime}: \text { degrees }\end{array}$ & $\begin{array}{c}\text { Effective } \\
\text { cohesion, } c^{\prime}: \mathrm{kPa}\end{array}$ \\
\hline Weald Clay embankment fill & 19 & 25 & 1 \\
Softened Weald Clay embankment fill & 19 & 19 & 1 \\
Weathered Weald Clay & 19 & 25 & 1 \\
Weald Clay & 20 & 30 & 5 \\
Rockfill & 19 & 35 & 0 \\
\hline
\end{tabular}




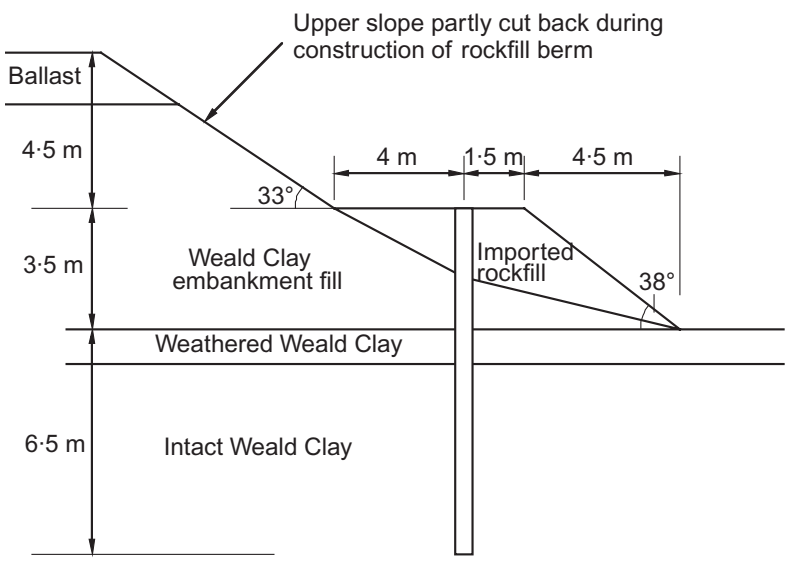

(a)

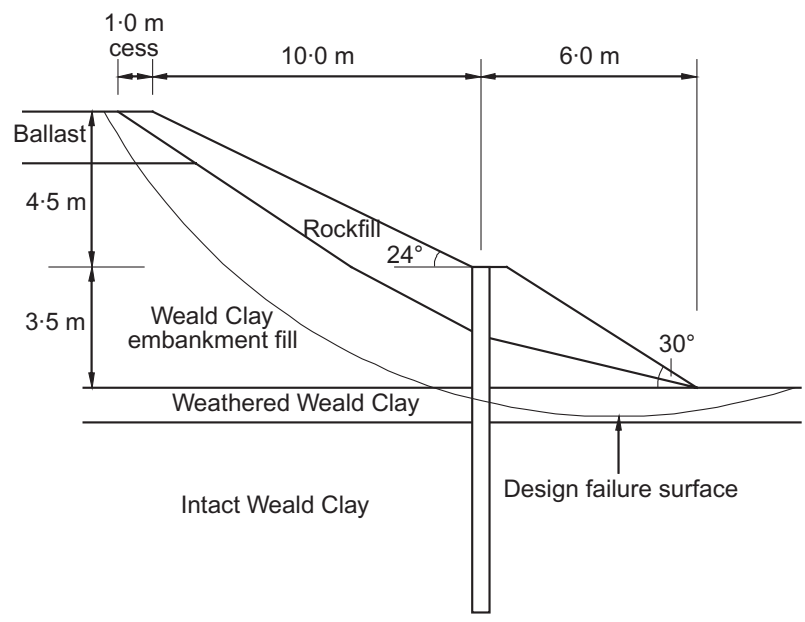

(b)

Fig. 4. Embankment profile: (a) from pile installation on 29 March 2001 to the start of regrading on 19 April 2001, showing rockfill berm used for pile installation; (b) from 20 April 2001 onwards

lation, with the row of piles modelled as a retaining wall rotating about a point a short distance above its base. The point force from the slope stability analysis was applied as a triangular pressure distribution acting over the length of pile within the failing mass.

The pile design calculation is based on the point force required to increase the factor of safety of the slope from a little above 1.0 (including the additional stability given by the rockfill berm) to $1 \cdot 3$. The increased factor of safety is to allow for future deterioration of the slope, and the actual restoring force needed to ensure the stability of the slope at the current time is likely to be smaller. Hence the actual or measured bending moments would be expected to be significantly smaller than the pile bending capacity specified.

\section{PILE AND SOIL DISPLACEMENTS}

Datum readings for the inclinometer tubes installed in the piles were taken on day 3 after pile installation, and for the tubes in the slope midway between the piles on day 5 . Several further sets of inclinometer readings were taken over the 4 years after pile installation.

The inclinometer data are analysed assuming that the bases of the piles have not displaced laterally. The inclinometer used gives readings to a resolution of $0.1 \mathrm{~mm}$ of lateral displacement for every $0.5 \mathrm{~m}$ depth, with a repeatability of measurement better than $\pm 1 \cdot 0 \mathrm{~mm}$.
The results from the inclinometer tubes in the slope midway between the piles are shown in Fig. 7 for day 42 (10 May 2001), shortly after the rockfill on the slope surface had been regraded, and day 1345 (01 December 2004). A movement of $7 \mathrm{~mm}$ over the top $4 \mathrm{~m}$ of the slope on day 42 has increased by day 1345 to about $25 \mathrm{~mm}$. The significant increase in displacement at about $4 \mathrm{~m}$ depth corresponds to the location of the critical failure surface identified in design and the depth of the slope failures recorded on adjacent sections of the embankment before remediation. Many old clay embankments were tipped too steep, and often failed during construction (Squire, 1880; Skempton, 1995): consequently the side slopes often contain relict shear surfaces. Following regrading of the rockfill, the slope has continued to move on what may be a pre-existing shear surface at about $4 \mathrm{~m}$ depth, just below the base of the embankment in the intact Weald Clay. Longitudinal displacements seem to indicate a small movement to the right, when looking downslope, possibly caused by the increasing height of the embankment in that direction.

Displacement data from the inclinometer tubes in Piles A, $\mathrm{B}$ and $\mathrm{C}$ are shown in Fig. 8. At day 42, the piles have moved about $6-8 \mathrm{~mm}$ at the head-similar to the soil midway between the piles. Piles $\mathrm{A}$ and $\mathrm{C}$ are bending slightly back upslope over the upper section, where the pile head is partially restrained in the failing mass. By day 1345 the pile movements have increased, with total pile-head movements of $35-38 \mathrm{~mm}$. The piles are much less restrained within the failing mass, and bending is most significant over the bottom $4 \mathrm{~m}$, where the pile base appears to be well fixed in the intact Weald Clay.

Figure 9 compares the average pile and soil displacements for days 42 and 1345. By day 1345, the relative soil/pile displacements are reasonably clear: between $2 \mathrm{~m}$ and $4 \mathrm{~m}$ depth, the slope displacements are up to $4 \mathrm{~mm}$ larger, and between $4 \mathrm{~m}$ and $8 \mathrm{~m}$ and above $2 \mathrm{~m}$ depth the piles displace up to $10 \mathrm{~mm}$ further than the soil. The measured pattern of relative soil and pile displacements is consistent with that indicated in Fig. 1(b).

\section{MEASUREMENT OF BENDING MOMENT \\ Bending moment calculation}

Standard engineering beam theory is used to convert the longitudinal strains $\varepsilon_{1}$ and $\varepsilon_{2}$ measured by each pair of strain gauges into bending moment $M$ :

$$
M=\frac{E I\left(\varepsilon_{1}-\varepsilon_{2}\right)}{y}
$$

where $y$ is the distance between the gauges in each pair.

Estimating the bending moment using equation (1) is not straightforward, because the flexural rigidity $E I$ of the piles varies with bending moment when the concrete is partly cracked. Uncracked behaviour is normally assumed in the analysis of field measurements of retaining walls (Tedd et al., 1984; Wood and Perrin, 1984), and has been used in the analysis of the results here. Thus the composite flexural rigidity, $E I$, was calculated as $187 \times 10^{3} \mathrm{kN} \mathrm{m}^{2}$ for the lower $7 \mathrm{~m}$ of the pile and $171 \times 10^{3} \mathrm{kN} \mathrm{m}^{2}$ for the top $3 \mathrm{~m}$, both using $E=25 \times 10^{6} \mathrm{kN} / \mathrm{m}^{2}$ for uncracked concrete (British Standards Institution, 1985). Concrete cracking and creep would be expected to reduce both the pile flexural rigidity and bending moments, compared with those calculated assuming uncracked behaviour.

It is desirable to take strain datums shortly after pile installation, as much of the concrete curing shrinkage that may affect the strain gauge readings occurs in the first few days after casting (Bakoss et al., 1977; Murdock et al., 


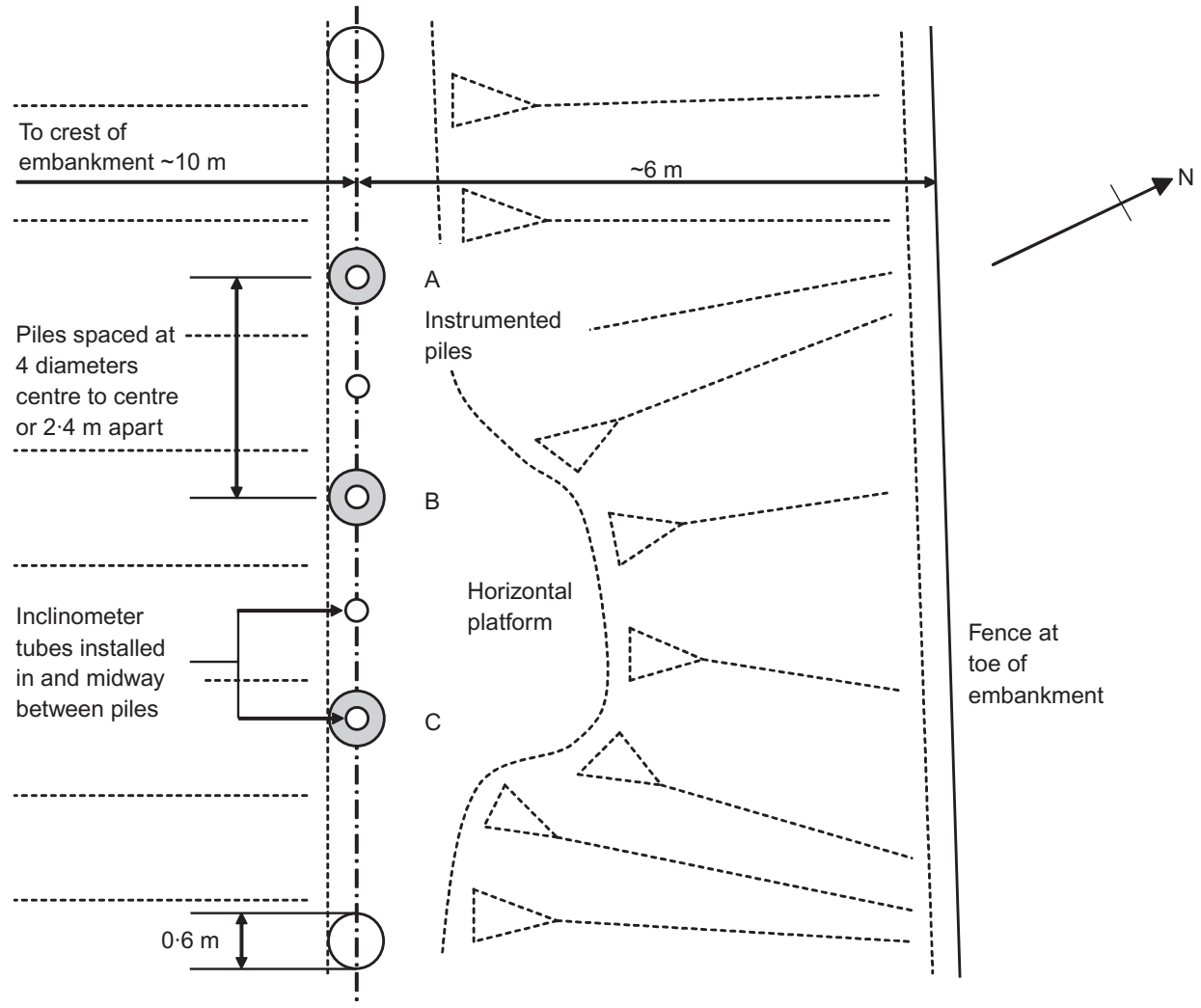

Fig. 5. Plan of instrumented section of slope, showing layout of instrumentation

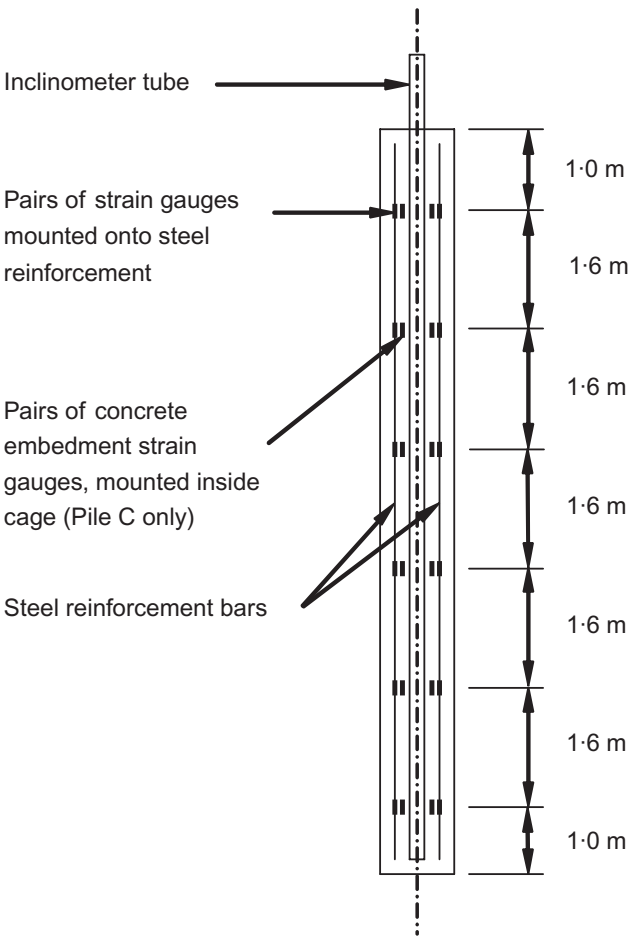

Fig. 6. Cross-section through instrumented piles, showing location of strain gauges and inclinometer tube

1991). In the current application this is possible only if it can be ascertained that the piles have not started to carry any load from the slope in the intervening period. For the piles at Hildenborough the datum for bending strain has been taken as the set of strain readings $4 \mathrm{~h}$ after the concrete had been poured, and the readings probably therefore include some shrinkage (Smethurst, 2003, discusses the effect of the shrinkage on the bending moment in more detail). A datum directly after pile construction was used because sections of the embankment were unstable prior to and during the period of pile installation in early April 2001, and it was considered that some slope movement occurred during the first few days after pile construction.

\section{Bending moment results}

After four years, some of the strain gauges in the piles have failed, making it harder to interpret the longer-term bending behaviour. Analysis of the bending strain will focus on Pile $\mathrm{C}$, because there are two sets of gauges in this pile and there have been fewer gauge failures. Distributions of bending moment with depth from the two sets of gauges in Pile $\mathrm{C}$ are shown for days 42 and 1345 in Fig. 10. Positive bending moments correspond to tension on the upslope side of the pile, or curvature of the pile downslope.

Figure 10 shows that significant bending moments developed in the piles within the first 40 days, and that the changes in bending moment since then have been relatively small. Comparison of the results from each of the sets of gauges shows some variation in the bending moments measured. While the distributions are broadly the same shape, in that there are negative moments at the top and toe of the pile and a positive moment in the middle, the exact depth and magnitude of the peak moments vary. Possible explanations for this include the effects on the different types of strain gauge of concrete cracking and shrinkage and pile cage installation.

Figure 11 shows the bending moment measured by the embedment gauges in Pile C plotted against time for each of the six measurement locations within the pile, together with the monthly rainfall totals for Kenley Airfield, South London, about $29 \mathrm{~km}$ from the site. The first increase in bending moment occurs at the very start, and is believed to be a genuine pile loading resulting from a slight movement of the slope. The main increase in bending strain occurred on days 


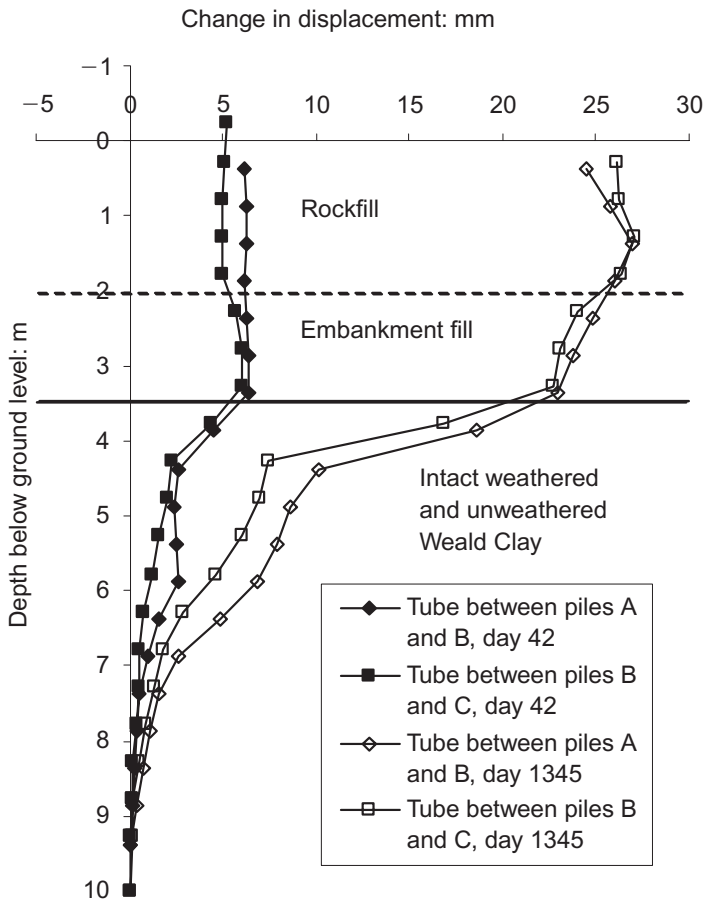

(a)

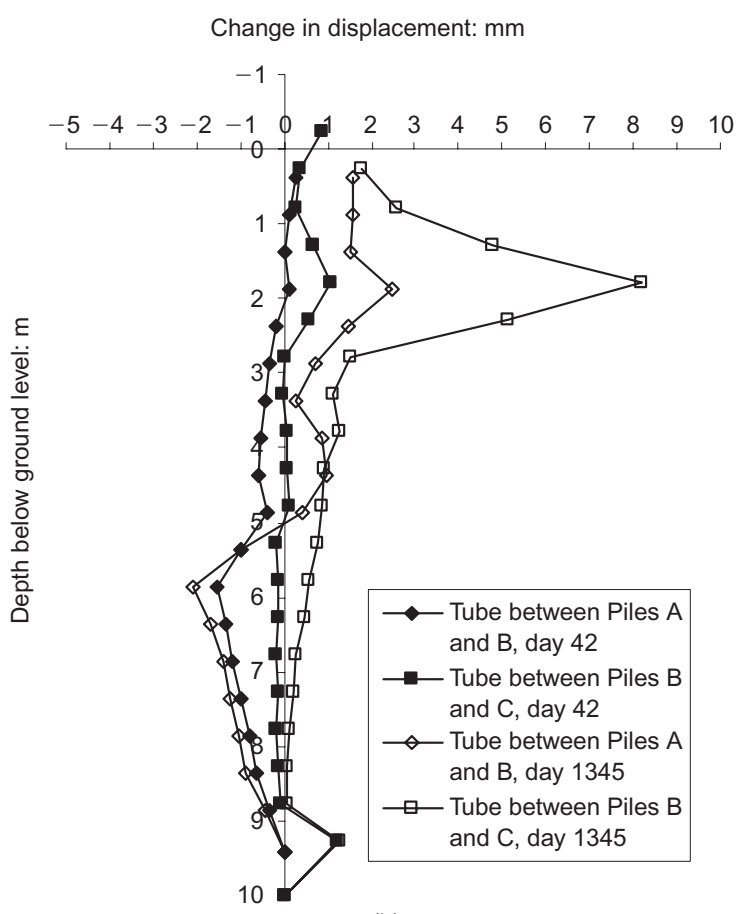

(b)

Fig. 7. Displacements from inclinameter tubes installed midway between the piles: (a) upslope-downslope displacements (with downslope displacements denoted positive); (b) across-slope displacements (with movements to right, when looking downslope, denoted positive)

22 and 23 after pile construction, when additional rockfill was placed upslope of the piles to add stability to the upper section of the slope and create a cess at the crest. There is then a series of smaller increases in bending moment at $4.2 \mathrm{~m}, 5.8 \mathrm{~m}$ and $7.4 \mathrm{~m}$ depth, but these do not reflect the significant increases in pile displacements seen over the same period (i.e. between day 42 and day 1345); this is discussed below.

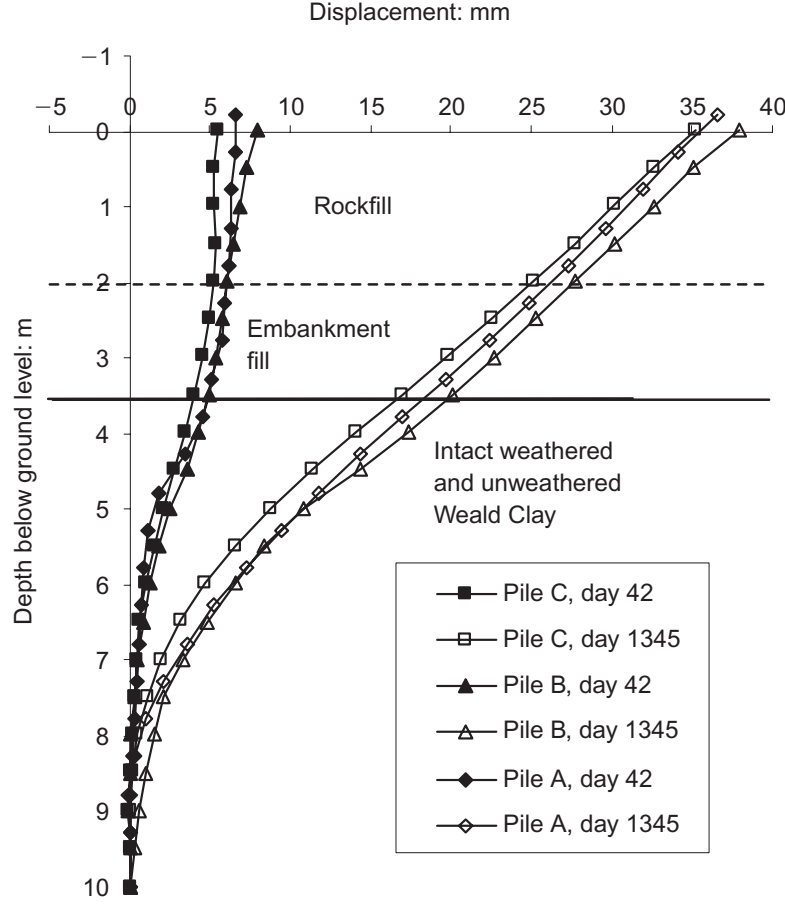

(a)

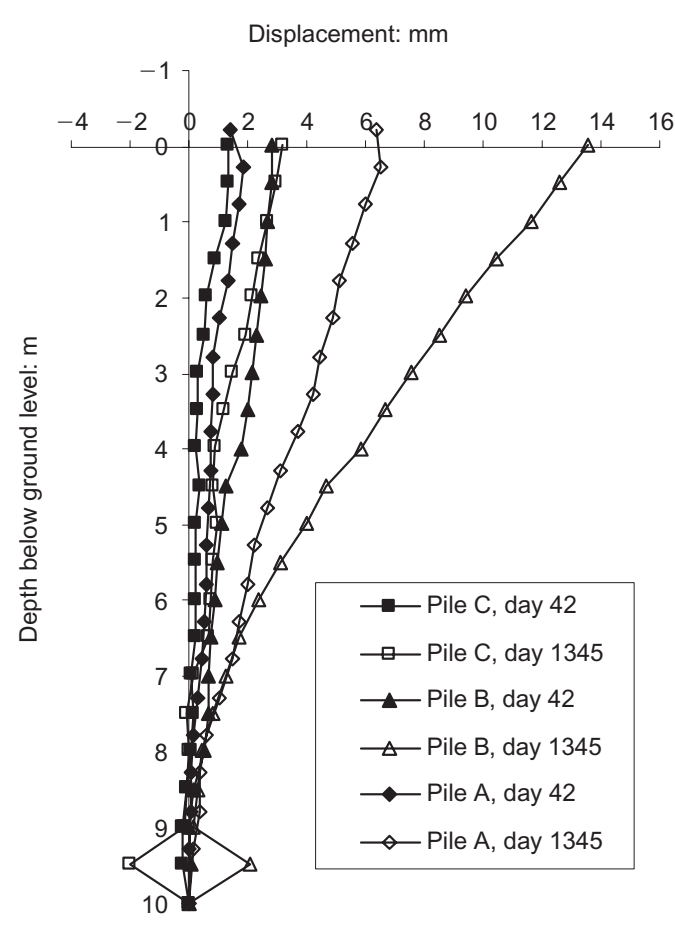

(b)

Fig. 8. Pile inclinometer displacements: (a) upslope-downslope displacements (with downslope displacements denoted positive); (b) across-slope displacements (with movements to right, when looking downslope, denoted positive)

\section{ANALYSIS OF PILE BENDING BEHAVIOUR}

The bending moment curve shown in Fig. 12(a) is the average of the bending moment data from both the sets of gauges in Pile $\mathrm{C}$ for day 42 (i.e. the average of the readings from the two sets of strain gauges at a given depth, or the reading given by the pair of gauges still functioning where one of the pairs of gauges has failed). A series of fourthorder polynomial splines (Georgiadis et al., 1992) has been fitted between the averaged bending moment data points in 
Displacement: $\mathrm{mm}$

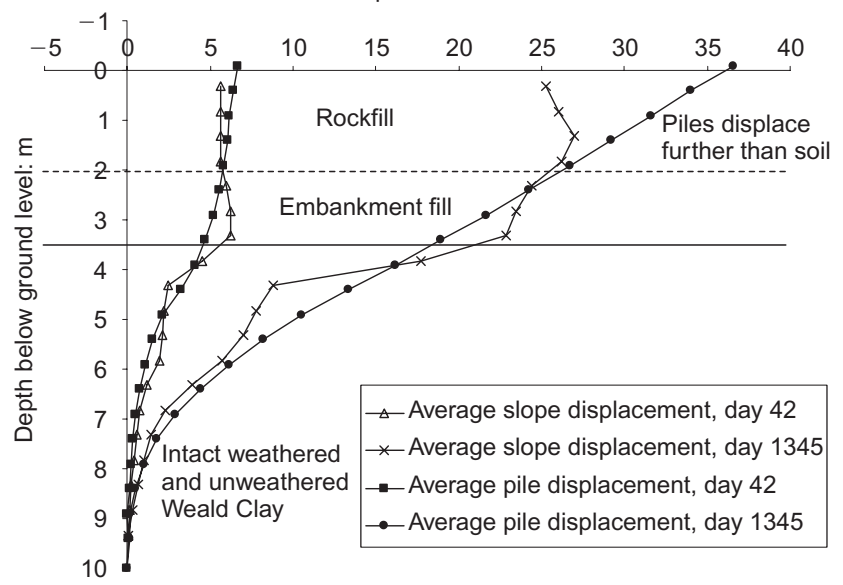

Fig. 9. Averaged measured pile and soil displacements

Fig. 12(a) and differentiated twice to derive the net soil pressure acting on the pile (Fig. 12(b)). (Note that, in Fig. 12(a), the spline does not quite pass through the data point at $1.0 \mathrm{~m}$ depth, as forcing it through this point causes the system of splines to become unstable.) The net pressures indicated in Fig. 12(b) are broadly consistent with the directions of relative soil/pile movement shown in Fig. 9.

It is also possible to determine both the pile bending moment and net pressure distributions from the pile displacements. The second curve in Fig. 12(a) shows the bending moment distribution determined by manipulating the spline so that, when integrated twice, it fits the inclinometer displacement data (Fig. 12(c)). The net pile pressure distribution obtained by differentiating this modified bending moment distribution twice is shown in Fig. 12(b). For day 42 the bending moments and net pressures consistent with the inclinometer displacement data match reasonably closely the distributions obtained directly from the strain gauge data. (Note that when integrating the bending moments to obtain the pile displacement, the pile stiffness was assumed to vary smoothly between 2 and $4 \mathrm{~m}$ depth, rather than increasing suddenly at $3 \mathrm{~m}$ depth to account for the increased reinforcement over the bottom $7 \mathrm{~m}$ of the pile.)

The corresponding data and calculations for day 1345 are shown in Fig. 13: the bending moment and net pressure distributions determined from the inclinometer displacement profile using the uncracked flexural rigidity exceed those determined from the strain gauges directly. This is particularly apparent between $4.5 \mathrm{~m}$ and $8.5 \mathrm{~m}$ depth, where the bending moments also exceed the cracking moment of the piles, $M_{\mathrm{cr}}$ (calculated in the Appendix).

When the pile section is cracked, the strain in the tension side of the pile is increased if measured across a crack, but reduced if measured between cracks (Clark \& Richards, 2005; Sousa Coutinho, 2006). Inspection of the bending strains shows that several of the strain gauge pairs indicated a larger compressive than tensile strain, suggesting that cracking has reduced the measured strain in the tension side of the pile and hence the overall bending strain. The strain gauge readings therefore take into account the cracking of the pile to some extent.

When calculating bending moments by integrating twice the spline fitted to the pile displacements (Fig. 13(c)), it is necessary to reduce the flexural rigidity $E I$ used between $4.5 \mathrm{~m}$ and $8.5 \mathrm{~m}$ depth to account for the effect of cracking. The fully cracked EI for the lower $7 \mathrm{~m}$ of the pile is $100 \times 10^{3} \mathrm{kN} \mathrm{m}^{2}(53 \%$ of the uncracked value), however, the pile is probably only partially cracked over much of this section, with the actual EI lying somewhere between the
Bending moment: $\mathrm{kNm}$

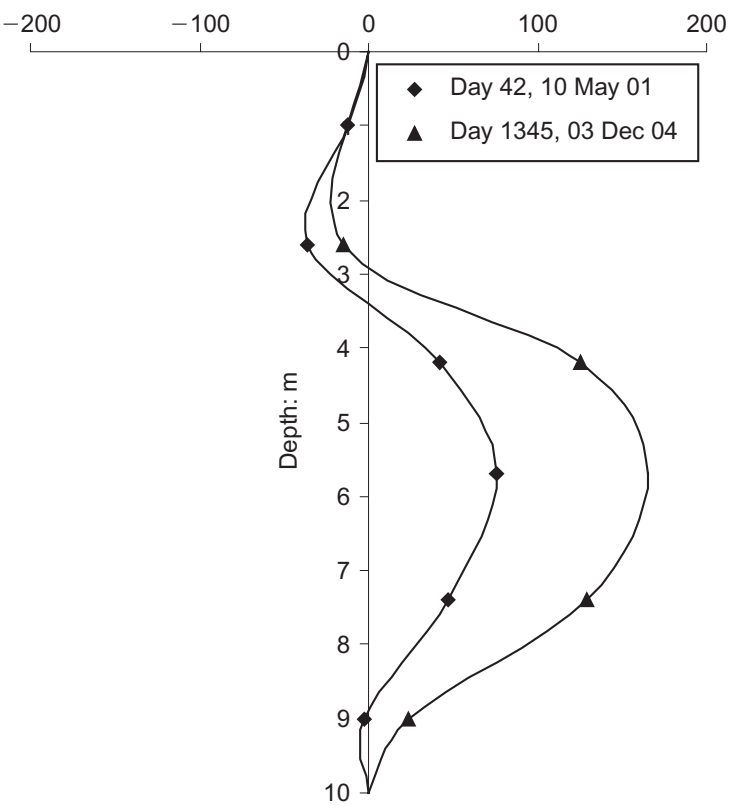

(a)

Bending moment: kNm

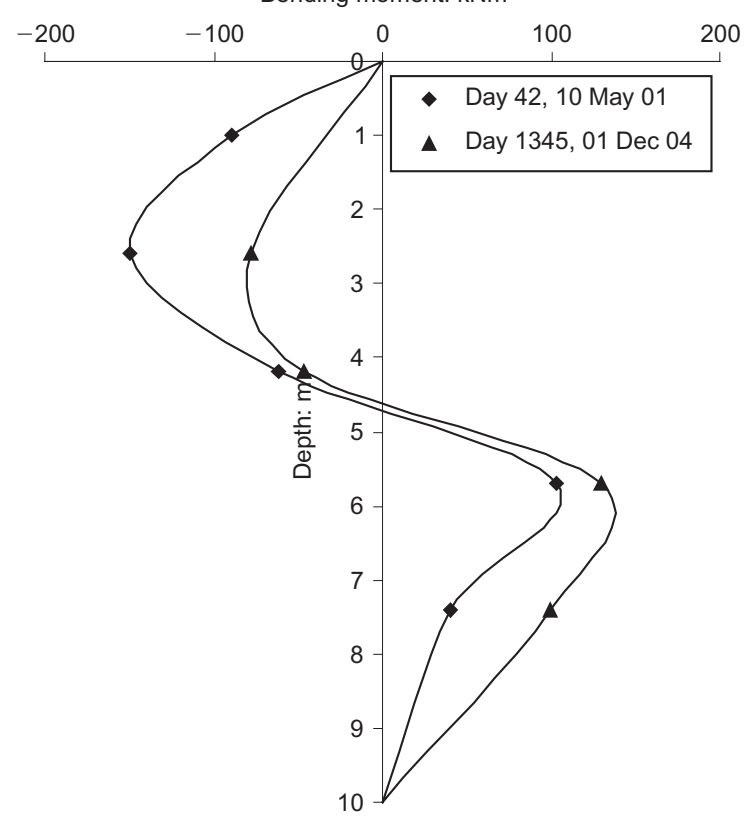

(b)

Fig. 10. Measured bending moment: (a) Pile $\mathrm{C}$ embedment strain gauges; (b) Pile $\mathrm{C}$ rebar strain gauges

cracked and uncracked values. It is not possible to calculate the partially cracked EI without knowing the bending moment acting in the section, and hence reliable adjustment of the calculated bending moment profile to account for cracking is very difficult. It is therefore likely that the strain gauge data give a better indication of the true bending moments and soil pressures than integrating the inclinometer displacements twice.

Figure 13(b) shows that the net pile pressure distribution for day 1345 is similar in profile to that on day 42, except over the bottom $3 \mathrm{~m}$ or so. Overall, the net pressure distributions are broadly consistent with the measured pattern of relative soil and pile displacements shown in Fig. 9.

While there were significant increases in the displacement 


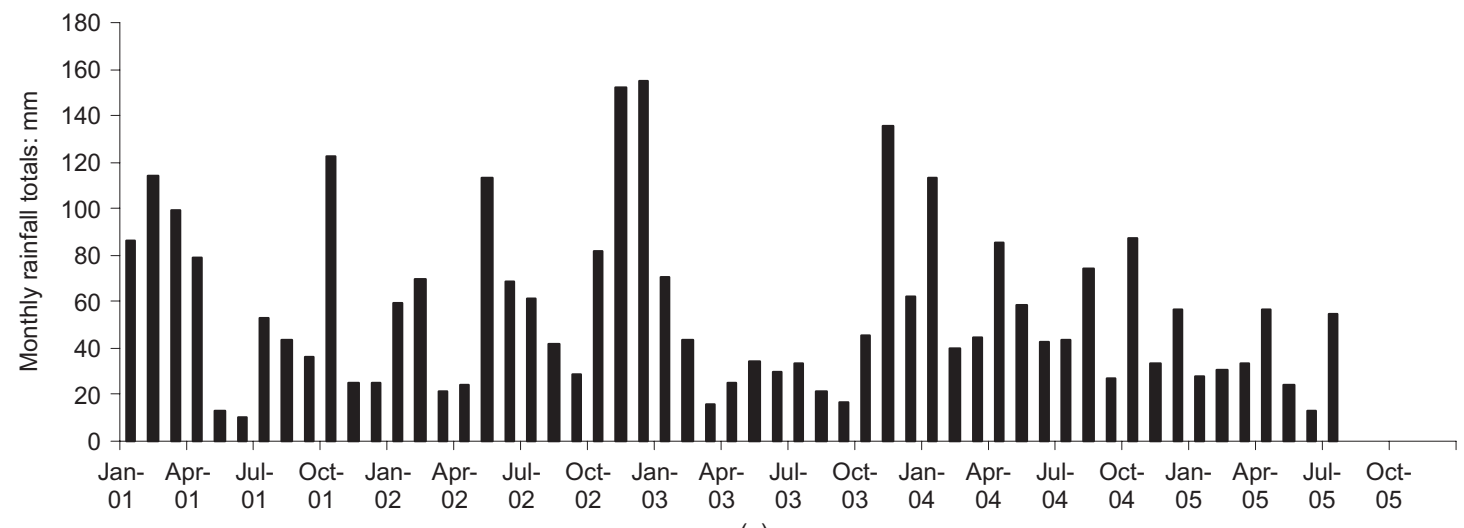

(a)

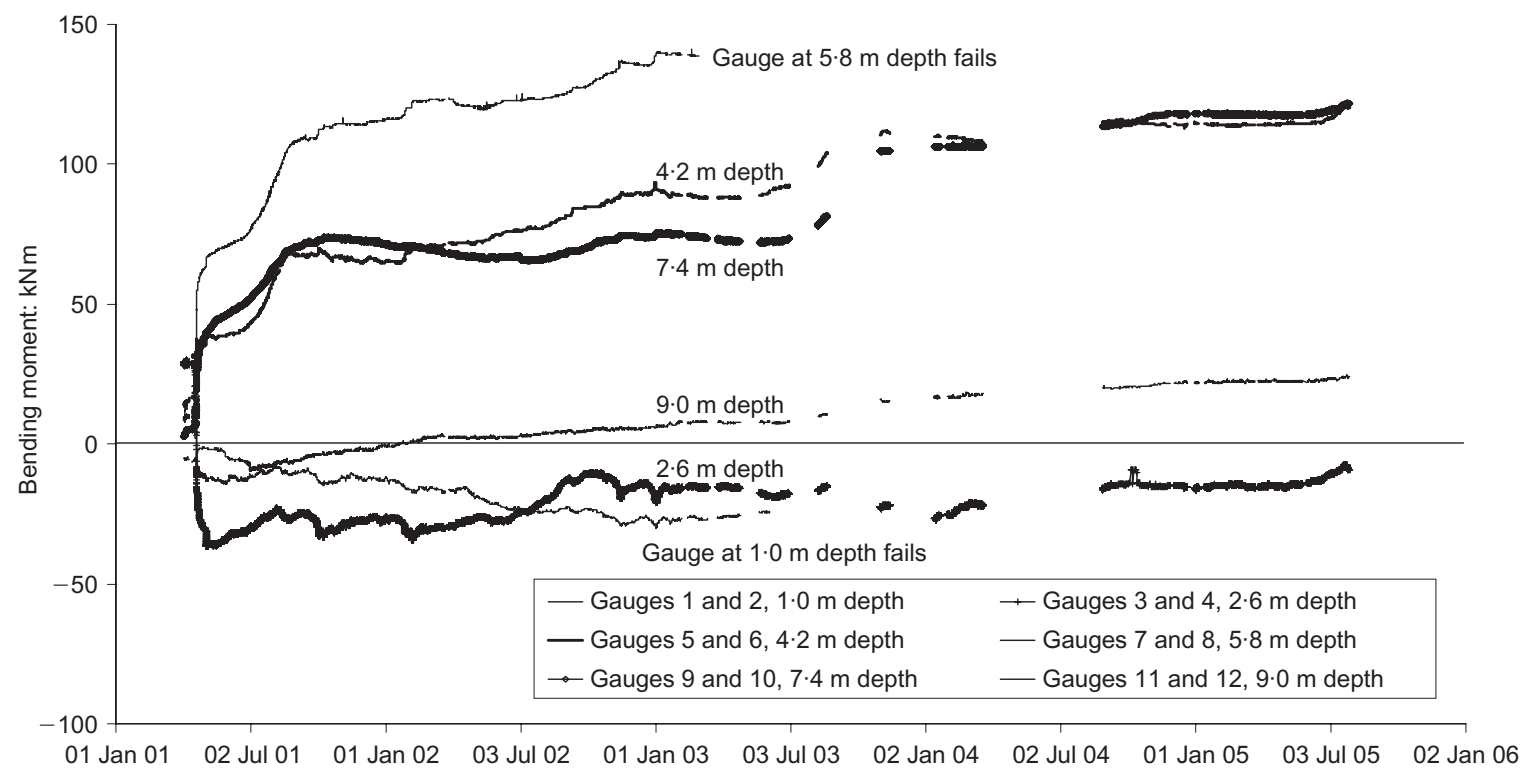

(b)

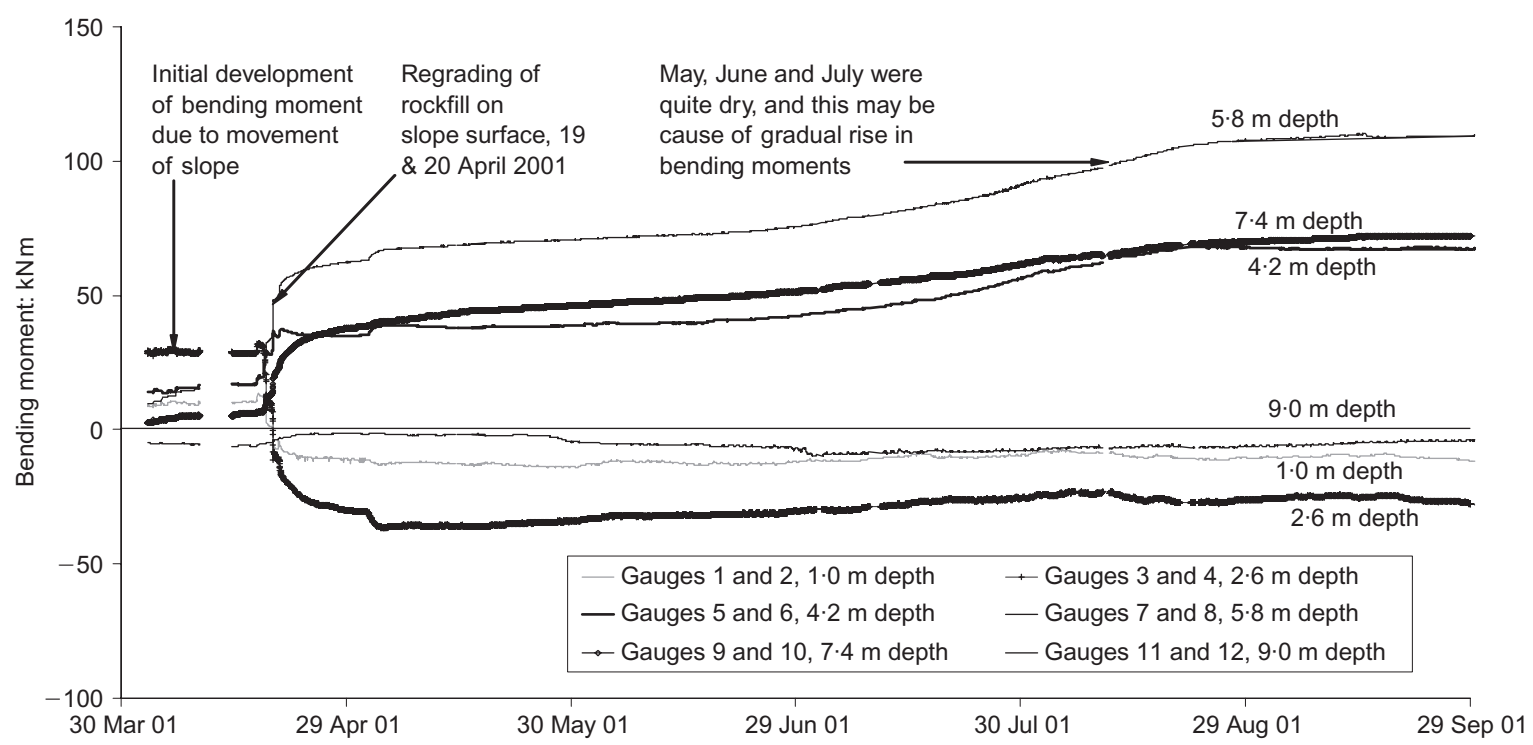

(c)

Fig. 11. (a) Rainfall data for Kenley, about $29 \mathrm{~km}$ from the Hildenborough site; (b) the moment in Pile C (embedment gauges) plotted with time for each of the six measurement locations within the pile and for the last 4 years; (c) first six months of data, showing the reasons for the increases in bending

of the pile head between days 42 and 1345 (Fig. 9), the changes in the net downslope pressures acting on the pile above the failure surface are relatively small (Figs 12(b) and 13(b)): this suggests that continued pile displacements have occurred with only a small change in loading from the slope.

Figure 11(b) shows that between days 42 and 1345 there were a series of small stepped increases in bending moment 


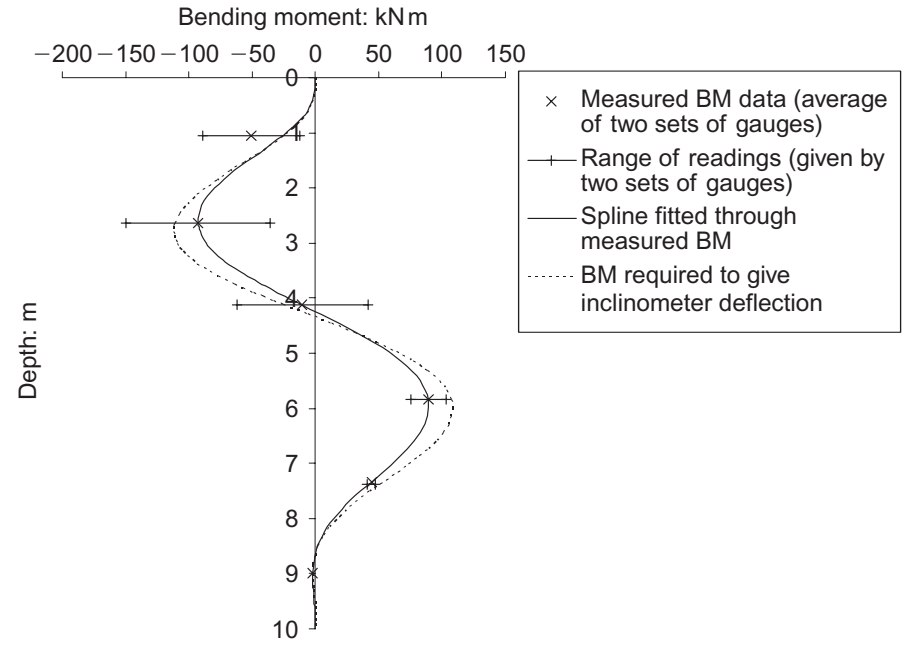

(a)

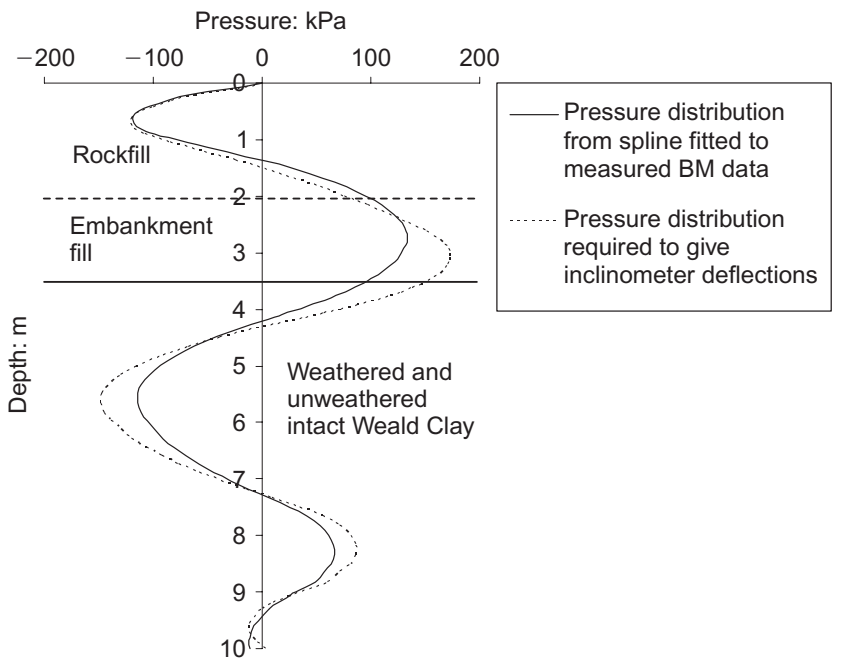

(b)

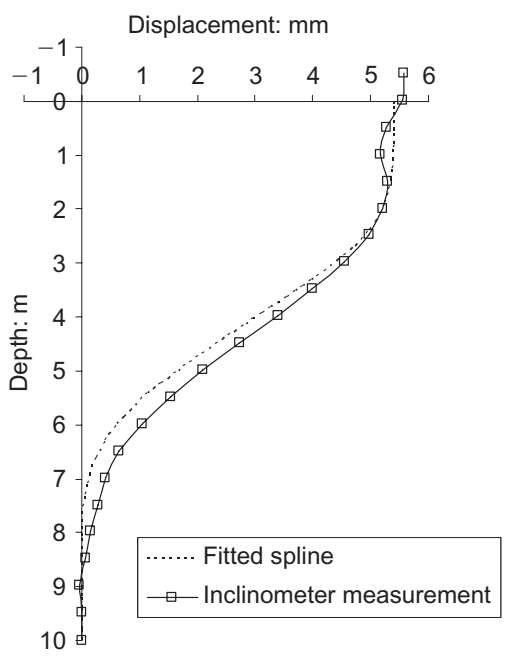

(c)

Fig. 12. Splines fitted to measured bending moment in Pile $C$ on day 42: (a) spline fitted between average of measured bending moment from two sets of gauges, and bending moment spline that (when twice integrated) aligns approximately with measured inclinometer displacements; (b) net pile pressure profile obtained by twice differentiating both splines in (a); (c) displacement spline and measured inclinometer displacements 


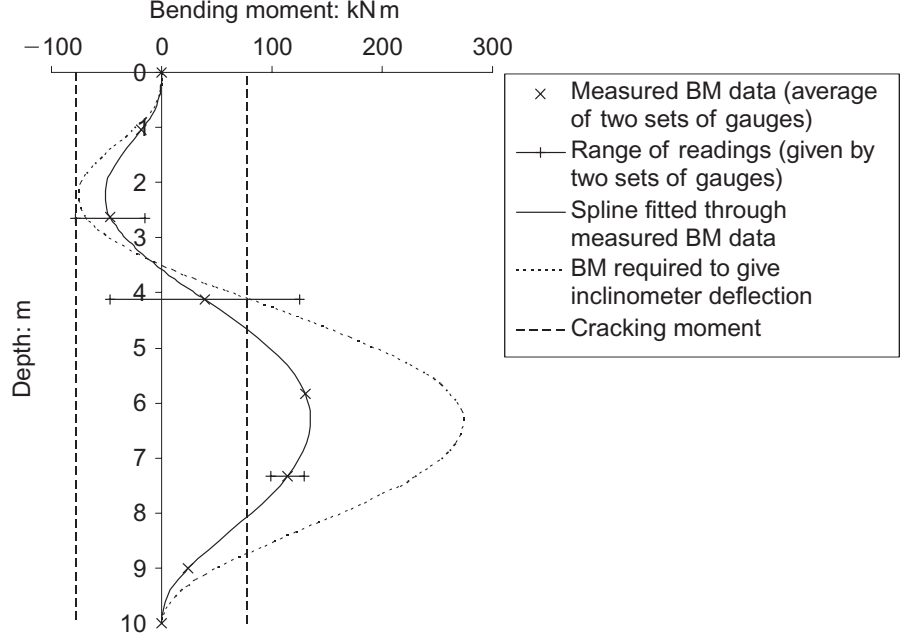

(a)

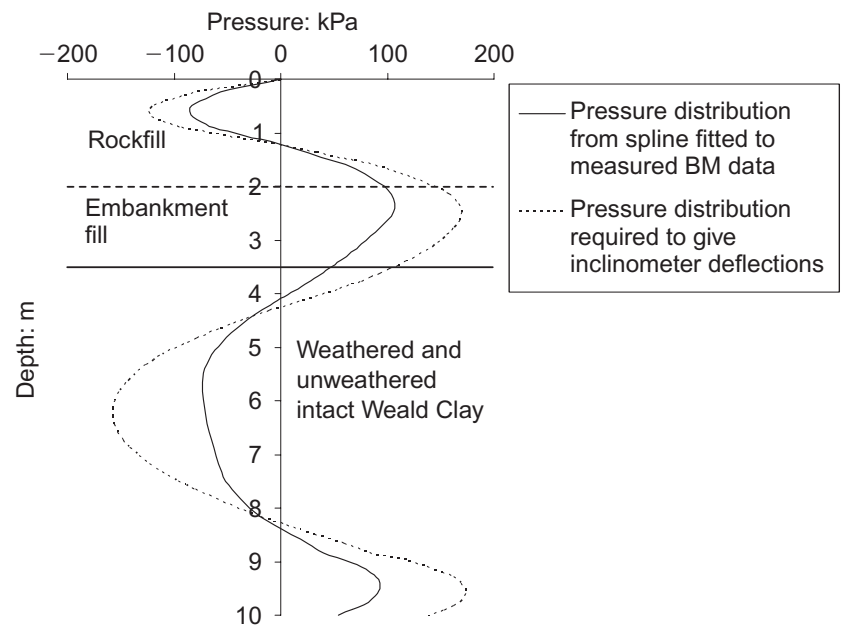

(b)

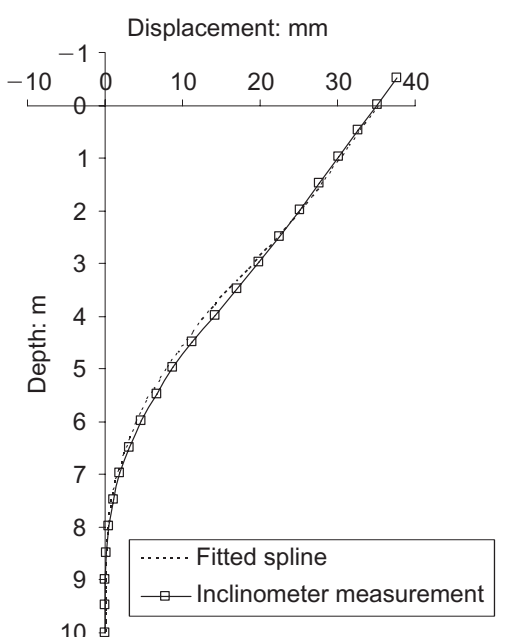

(c)

Fig. 13. Splines fitted to measured bending moment in Pile $C$ on day 1345: (a) spline fitted between average of measured bending moment from two sets of gauges, and bending moment spline that (when twice integrated) aligns with measured inclinometer displacements; (b) net pile pressure profile obtained by twice differentiating both splines in (a); (c) displacement spline and measured inclinometer displacements

measured by the strain gauges at $4.2 \mathrm{~m}, 5.8 \mathrm{~m}$, and $7.4 \mathrm{~m}$ depth. These are most noticeable during June and July 2001 and during the summer of 2003 - both periods of low rainfall (Fig. 11(a)). Suctions developing in the surface of the clay slope during the summer will act to stabilise the slope, and would not be expected to cause additional pile loading. However, other mechanisms may be postulated: summer surface drying of the clay (most likely caused by the mature 
trees at the toe of the slope) will cause it to crack, possibly removing support on the downslope side of the pile, and hence increasing the net downslope pressure on the pile and causing it to move to find a new equilibrium. This suggests that much of the pile movement may have been caused by the wetting and drying of the embankment, and possibly also a reduction in the pile flexural rigidity as it cracked, rather than by large increases in slope loading. However, the absence of any displacement measurements downslope of the pile row, or indeed pore water pressure measurements, means that such an interpretation must remain speculative.

\section{ELASTIC ANALYSIS OF THE PILES}

The observed pile behaviour at Hildenborough was backanalysed using the program ALP (Oasys, 2004), which models the pile as a series of finite beam elements attached to elastic-plastic springs that represent the soil. The pile can be loaded by displacing the soil at the surface into the top section of the model pile, replicating the behaviour of a real pile installed in a failing slope. The vertical pile/soil frictional interface is not fully modelled, and the soil is assumed to be attached to the pile.

The program uses an iterative calculation sequence. For a given pile displacement, the soil pressures are calculated initially assuming elastic behaviour. If the calculated soil pressures infringe the plastic yield criterion, the nodal forces are redistributed onto neighbouring pile beam elements.

\section{Model pile}

The pile was modelled as a series of 40 elastic beam elements, each $0.25 \mathrm{~m}$ long. The full uncracked flexural rigidity was used for the pile, except over a section between 4.5 and $8.5 \mathrm{~m}$ depth over which the pile was assumed to be partially cracked, with a flexural rigidity of $75 \%$ of the uncracked value.

\section{Limiting soil-pile pressure}

The soil profile used in the analysis of the piles is shown in Table 2. In the absence of detailed pore water pressure data, the pore pressures were assumed to be hydrostatic below, and zero above, a depth of $3.5 \mathrm{~m}$. The vertical effective stress was calculated using a unit weight for all soil materials $\gamma=19 \mathrm{kN} / \mathrm{m}^{3}$. For a soil at passive failure in plane strain,

$$
\sigma_{\mathrm{h}}^{\prime}=K_{\mathrm{p}} \sigma_{\mathrm{v}}^{\prime}+c^{\prime} \cot \phi^{\prime}\left(K_{\mathrm{p}}-1\right)
$$

where $K_{\mathrm{p}}$ is the coefficient of passive earth pressure $((1+$ $\left.\left.\sin \phi^{\prime}\right) /\left(1-\sin \phi^{\prime}\right)\right)$. Following Broms (1964), limiting lateral pressures on the pile $p_{\mathrm{u}}$ of three times the plane strain values were used in the analysis, to account for threedimensional effects.

The limiting lateral pile-soil pressure (or yield load) would be expected to be lower on the downslope side of the pile, where the ground profile drops away from the top of the pile. However, ALP assumes that the ground surface is horizontal; it is not able to differentiate the limiting condition for net upslope and downslope pressures on the pile. Hence the limiting pressures for horizontal ground were used. However, most of the upslope resistance to pile movement is below $3.5 \mathrm{~m}$ depth (the height of the rockfill berm) and, except for the very top of the pile, the lateral limiting pressure is much larger than the pressures acting on the pile, and the elastic-plastic springs representing the soil remain in the elastic zone.

The use of three times the plane-strain value over the full depth of the pile is likely to be an oversimplification: at the very top of the pile the limiting pressures may be expected to be closer to the plane-strain value, at the base possibly a multiple greater than 3 (Fleming et al. 1985). The adoption of limiting pressures based on $p_{\mathrm{u}}$ assumes that the piles act individually; at a spacing of 4 pile diameters there may be some interaction (arching) between the piles, which would tend to reduce slightly the limiting pressure for each individual pile (Chen \& Poulos, 1997; Chen \& Martin, 2002).

$p-y$ curves

A non-linear relationship between the relative soil-pile displacement and pressure (termed the $p-y$ curve) was used in the analysis, based on the representative values for a stiff clay given in API RP2A (API, 1984), of $p / p_{\mathrm{u}}=0,0 \cdot 24$, $0.50,0.72,1.0$ at $y / y_{\mathrm{c}}=0,0.2,1.0,3.0,8.0$ respectively, where

$$
y_{\mathrm{c}}=2 \cdot 5 \varepsilon_{50} D
$$

$\varepsilon_{50}$ is the strain at half the maximum deviator stress in an undrained triaxial compression test, and $D$ is the pile diameter.

$\varepsilon_{50}$ was estimated from triaxial tests carried out as part of the embankment geotechnical investigation, and compared favourably with other data for stiff clays (mainly London Clay). $\varepsilon_{50}=0.005$ was used for both the Weald Clay embankment fill and the underlying intact Weald Clay. In the absence of data, the stiffness of the rockfill $\varepsilon_{50}$ was taken as 0.002 .

\section{Soil displacements}

The soil displacements imposed on the upper section of the model pile (labelled D1 and D2) are shown in Fig. 14, together with the measured soil displacements.

\section{Results from the elastic analysis}

The ALP bending moment, displacement and net pressure results for the analysis with imposed soil displacements D1 (representing the measured soil displacements on day 42) are shown in Fig. 15. Also plotted in Fig. 15 are the

\begin{tabular}{|c|c|c|c|c|c|}
\hline \multirow[t]{2}{*}{ Soil layer } & \multirow[t]{2}{*}{ Depth range: $\mathrm{m}$} & \multirow{2}{*}{$\begin{array}{c}\text { Friction angle, } \\
\phi^{\prime}: \text { degrees }\end{array}$} & \multirow{2}{*}{$\begin{array}{c}\text { Effective cohesion, } \\
\qquad c^{\prime}: \mathrm{kPa}\end{array}$} & \multicolumn{2}{|c|}{ Passive resistance coefficient } \\
\hline & & & & $\begin{array}{l}\text { Frictional component of } \\
\text { soil strength, } 3 K_{\mathrm{p}}\end{array}$ & $\begin{array}{c}\text { Effective cohesion } \\
\text { component of soil } \\
\text { strength, } 3 \cot \phi^{\prime}\left(K_{\mathrm{p}}-1\right)\end{array}$ \\
\hline $\begin{array}{l}\text { Rockfill } \\
\text { Embankment fill } \\
\text { Weathered Weald Clay } \\
\text { Intact Weald Clay }\end{array}$ & $\begin{array}{r}0-2 \cdot 0 \\
2 \cdot 0-3 \cdot 5 \\
3 \cdot 5-4 \cdot 5 \\
4 \cdot 5-10 \cdot 0\end{array}$ & $\begin{array}{l}35 \\
25 \\
25 \\
30\end{array}$ & $\begin{array}{l}0 \\
1 \\
1 \\
5\end{array}$ & $\begin{array}{r}11 \cdot 07 \\
7 \cdot 38 \\
7 \cdot 38 \\
9 \cdot 00\end{array}$ & $\begin{array}{r}11 \cdot 51 \\
9 \cdot 45 \\
9 \cdot 45 \\
10 \cdot 40\end{array}$ \\
\hline
\end{tabular}

Table 2. Parameters used to calculate limiting lateral soil pressure 


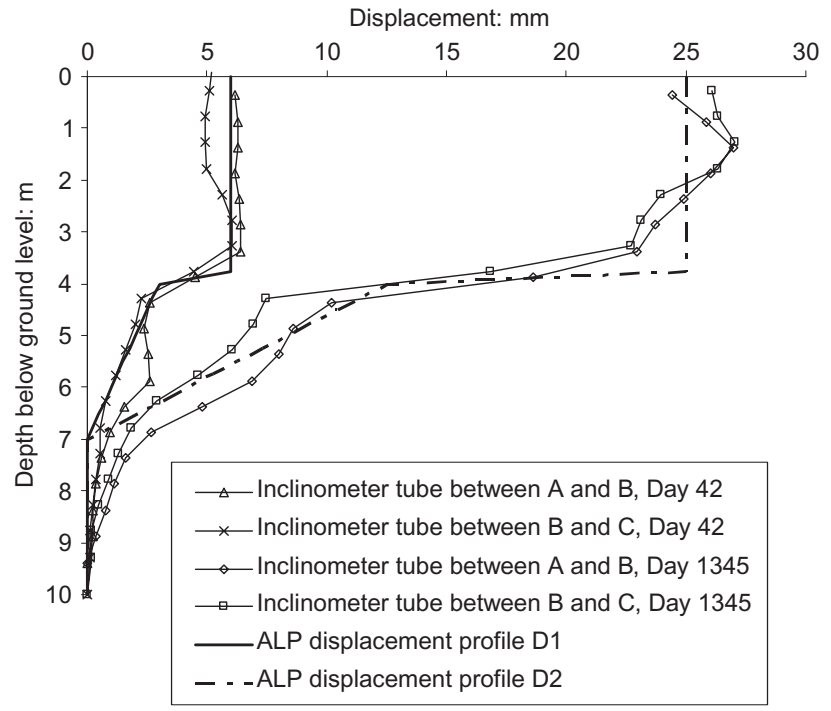

Fig. 14. Imposed soil displacements used in ALP

inclinometer data, and the bending moment and net pressure distributions obtained by differentiating splines fitted both to the strain gauge data points and to the inclinometer data. The shape of the pile bending moment distribution calculated using ALP is similar to that measured; however, the magnitude of the maximum bending moments is underestimated by ALP. In Fig. 15(c), differentiating the bending moment spline leads to a pressure distribution that is smoothed and does not reflect the abrupt changes in net pressure calculated close to the major plane of movement.

Figure 16 shows the bending moments, displacements and net pressure distributions calculated using ALP for the imposed soil displacements D2 (representing the measured soil displacements on day 1345). The measured and ALP D2 bending moments (Fig. 16(a)) are a reasonable match, although the ALP bending moments are about twice those measured on the upper part of the pile. The ALP pile displacements (Fig. 16(b)) slightly underestimate those measured, particularly over the top $3 \mathrm{~m}$ of the pile. This may be caused by the simplified distribution of soil movement used in the ALP analysis, which is smaller than the measured soil displacements over the top $2 \mathrm{~m}$ depth (Fig. 14). The rockfill $p-y$ curves may also have too large a secant stiffness at the displacements applied. This gives rise to the larger-thanmeasured negative bending moments (Fig. 16(a)) and net pressures (Fig. 16(c)) on this section of the pile.

\section{Discussion of ALP results}

Overall, the measured pile behaviour is well represented by the ALP analyses using estimated $p-y$ curves for day 42 . The fit is less close for day 1345, for which ALP calculates pile pressures and bending moments significantly larger than those measured. The influence of the rockfill on the piles is not quite correctly modelled in the ALP analyses.

Figure 16(c) shows that between $1 \mathrm{~m}$ and $4 \mathrm{~m}$ depth the calculated and measured net pressures are on average perhaps about half the limiting pile-soil pressure $p_{\mathrm{u}}$ (although the ALP analysis D2 clearly overestimates the measured net pressures). However, pile pressures are nowhere near $p_{\mathrm{u}}$ over the lower $6 \mathrm{~m}$ of the pile; this suggests that the pile is likely to fail in bending before the limiting pressures are reached over much of the length of the pile. Furthermore, it is apparent that, with the soil stiffnesses used, very large displacements would be needed to mobilise $p_{\mathrm{u}}$; such displacements are likely to be unacceptable where the piles are being used to prevent movement of an infrastructure embankment.

It would be possible to use a beam on springs (ALP-type) analysis as a serviceability check in design by imposing soil displacements in the zone above the critical slip surface to give a net pile pressure equivalent to the required pile load obtained from a limit equilibrium slope stability analysis. A pattern of soil movements below the critical slip surface would also need to be assumed, perhaps of the form indicated in Fig. 14.

\section{IMPLICATIONS FOR DESIGN}

The measured bending behaviour of the piles differs from that assumed in design, as a result of the near-surface upslope pressure where the pile rotates into the soil. The reason for this was illustrated in Fig. 1, but in this study the effect may have been exacerbated by the relatively stiff and strong rockfill layer. In situations where such a layer is not placed, the smaller stiffness and strength of the near-surface soil would be expected to reduce the magnitude of the upslope pressures, compared with a rockfill layer. The effect of an upslope near-surface pressure cannot be modelled in a simple limit equilibrium calculation, as it introduces a further unknown, making the problem statically indeterminate. A simple limit equilibrium calculation might lead to a conservative estimate of the maximum bending moment, but further field data from other case studies are needed to develop design guidance on this point.

The use of a soil-structure interaction program such as ALP may represent a possible design approach that would overcome the statically indeterminate nature of the problem. However, it requires assumptions to be made about displacements, which may be difficult to justify, especially over the design life of the structure. Again, further development of the approach as a design method is required.

\section{OVERALL PILE SCHEME PERFORMANCE}

The piles have been successful in preventing failure of the embankment slope. While the pile displacements are about $35-40 \mathrm{~mm}$ at the head, displacements of this order are required in this type of scheme to mobilise the pile-soil pressures needed to stabilise the failing mass of soil. The average rate of movement of the slope has been about $5.5 \mathrm{~mm} /$ year since installation of the piles and regrading of the rockfill; prior to pile installation, a similar amount of movement occurred in just one week in parts of the embankment. The piles have considerable reserve bending capacity, and the pile-soil pressures are significantly less than the limiting values at which the soil would start to flow around the piles.

Increases in lateral pile load may occur as a result of continuing increases in pore pressure following the removal of mature vegetation. Continuing pile movements may be associated with both seasonal cycles of wetting and drying in the embankment and the progressive reduction in the pile flexural rigidity as the concrete section cracks and creeps.

\section{CONCLUSIONS}

(a) Field measurements have identified the mechanism of slope and pile movement and the pile loading based on the relative pile and soil displacements. Pile displacement exceeded the slope displacement both beneath the critical failure surface at about $4 \mathrm{~m}$ depth, and over the top $1 \mathrm{~m}$ of the pile within the failing mass. Over the remaining $3 \mathrm{~m}$, the pile displacements were smaller than those in the soil. 


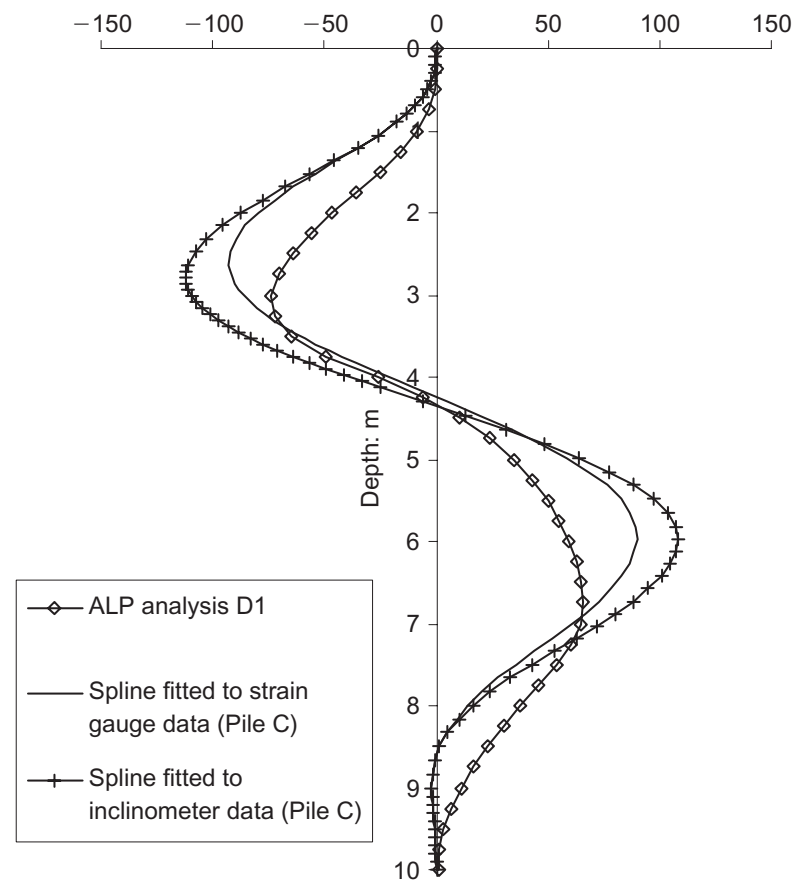

(a)

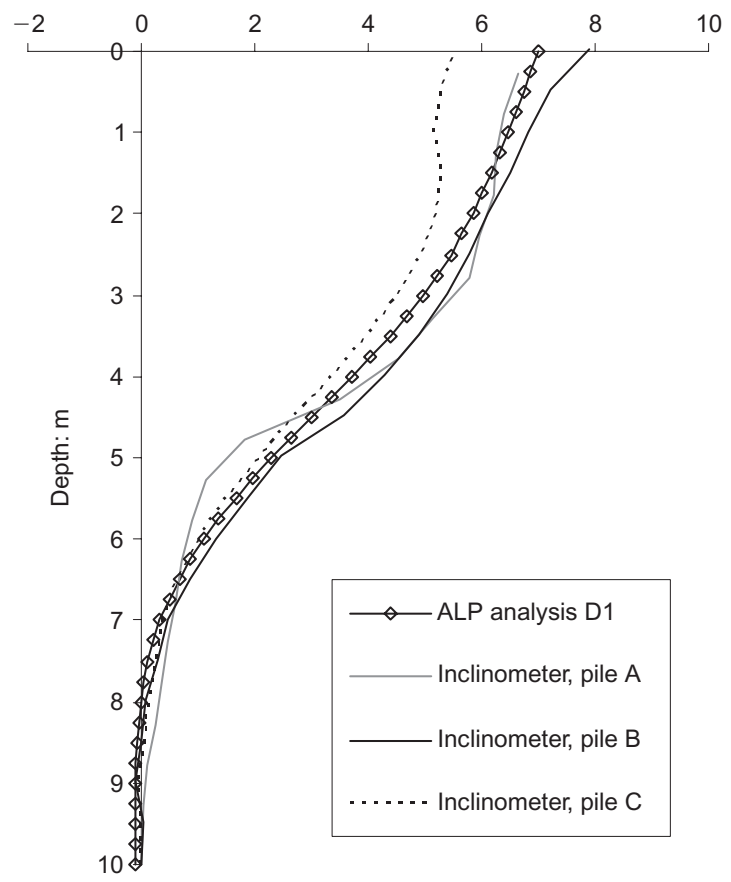

(b)

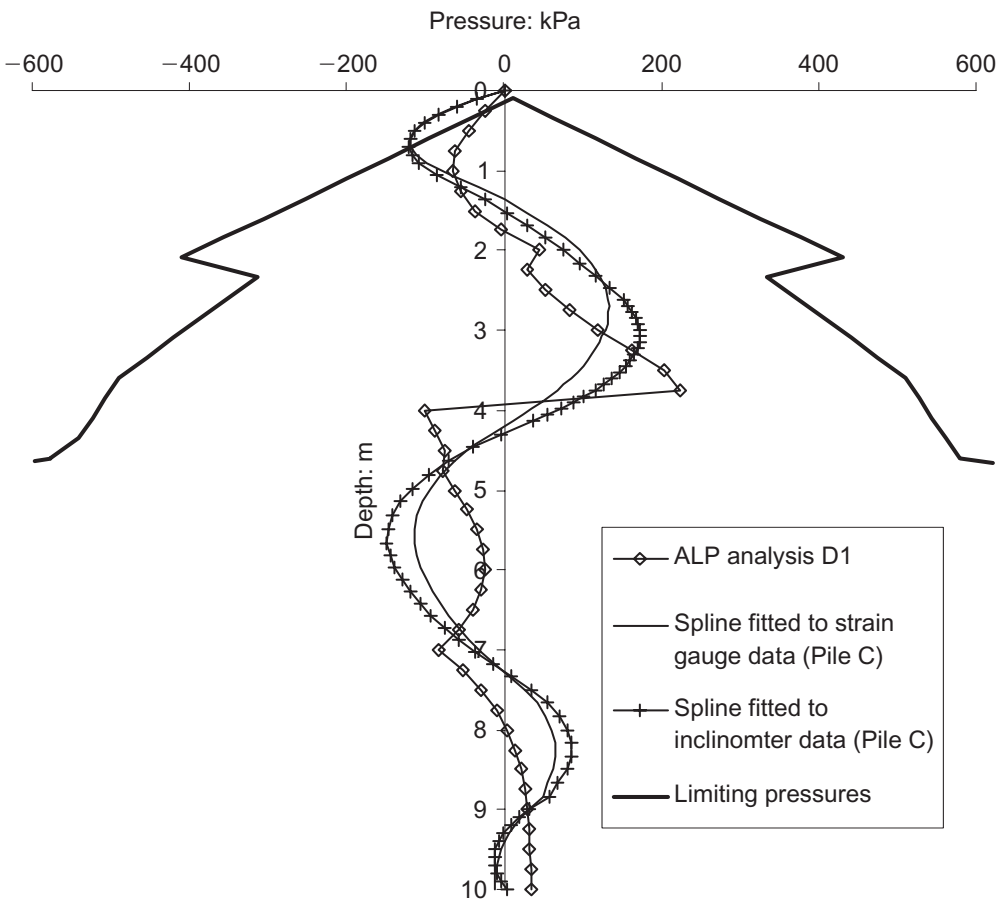

(c)

Fig. 15. Results of the ALP analyses with imposed soil displacement profile D1 (representing measured soil displacements for day 42): (a) calculated bending moments plotted with measured distributions; (b) calculated displacements plotted with inclinometer results; (c) calculated pressures plotted with pressure distributions determined by differentiating fitted bending moment distributions. Positive pressure acts downslope

(b) In the short term, the net pressure distribution obtained by differentiating the strain gauge data and the inclinometer data show close agreement. The net pressures calculated from the bending moment distributions confirmed the pattern of pile loading inferred from the relative pile and soil displacements.

(c) In the long term, the measured bending moments exceeded the cracking moment over a section of the pile. As cracking of the pile is likely to cause a reduction in the strain measured by the gauges on the tension side of the pile, the full flexural rigidity may still be used to calculate the bending moment and net pressure distributions from the strain data. In contrast, calculation of a bending moment distribution from the inclinometer data would require the use of a reduced flexural rigidity over the affected section of the pile.

(d) Regrading of the rockfill on the slope applied a significant part of the measured pile loading. In the 


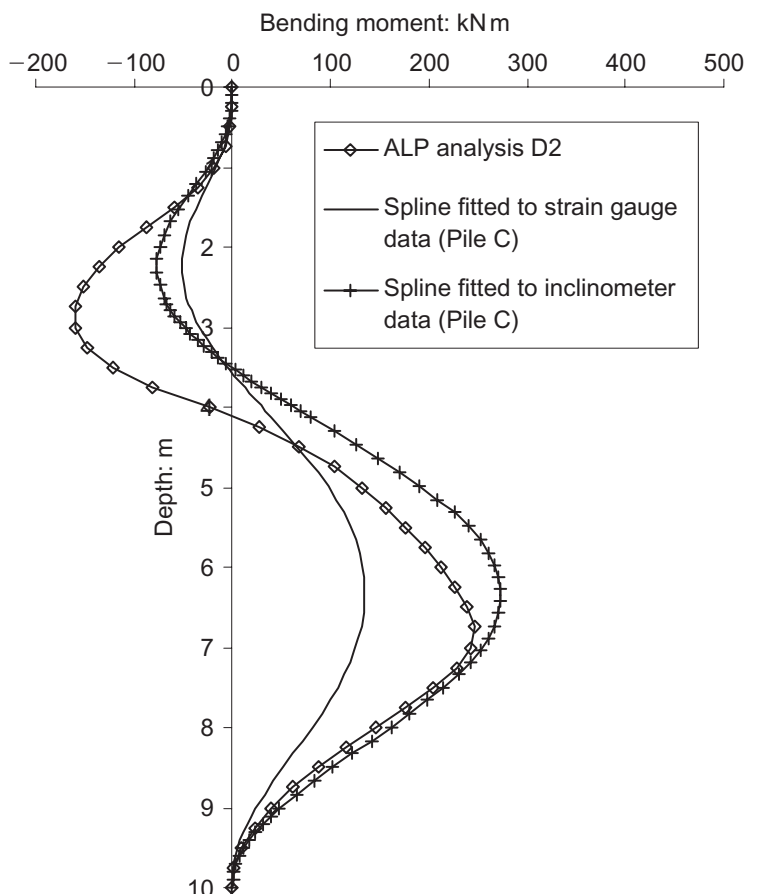

(a)

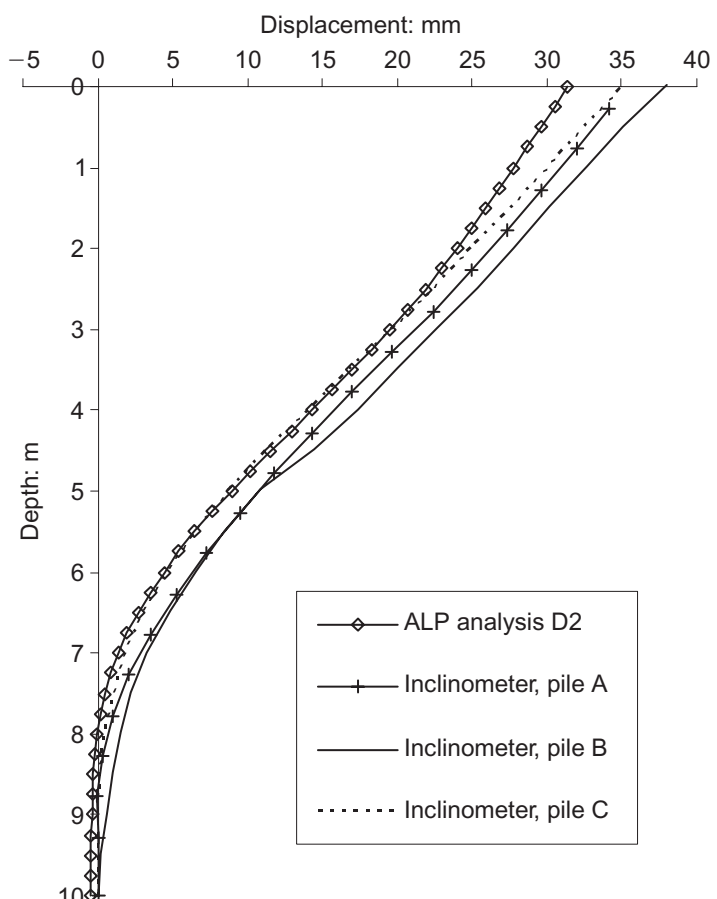

(b)

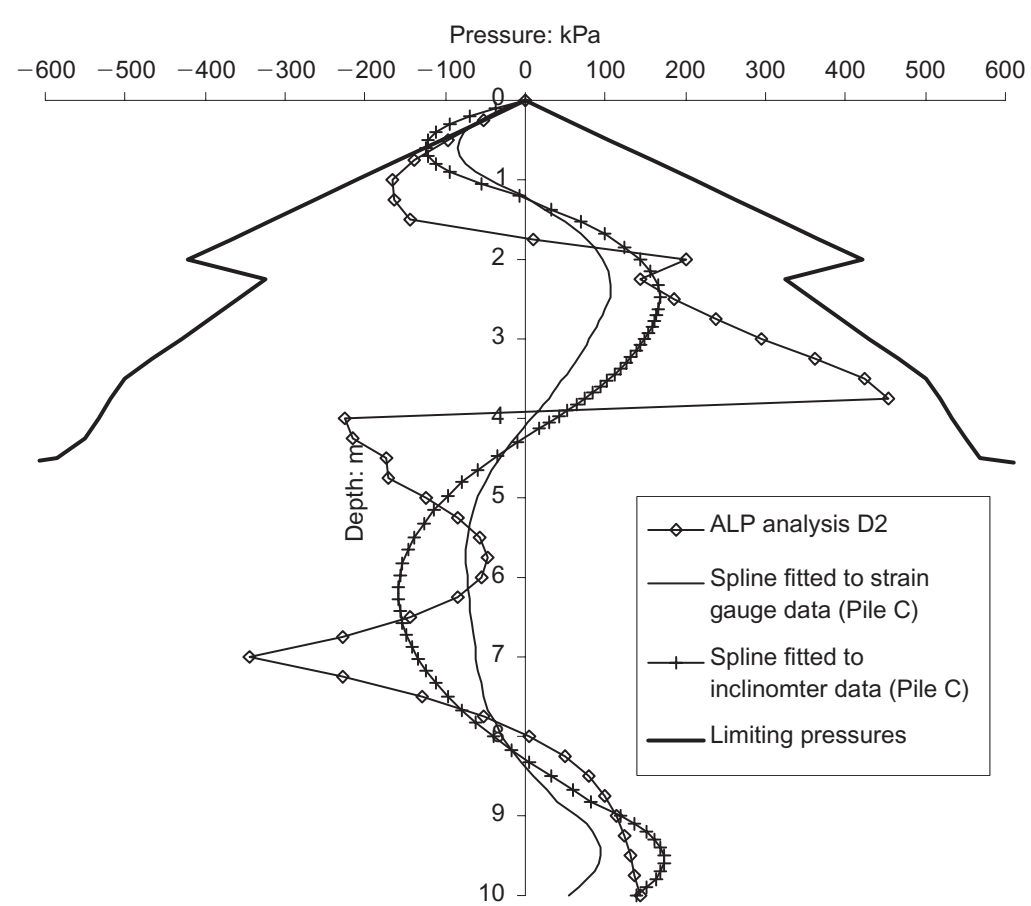

(c)

Fig. 16. Results of ALP analyses with imposed soil displacement profile D2 (representing measured soil displacements for day 1345): (a) calculated bending moments plotted with measured distributions; (b) calculated displacements plotted with inclinometer results; (c) calculated pressures plotted with the pressure distributions determined by differentiating fitted bending moment distributions. Positive pressure acts downslope

longer term, there have been increases in bending moments during the summer months. Although the exact mechanism for this is not clear, it may be that seasonal shrinkage and cracking of the clay allow a lateral movement of the pile.

(e) Simple beam-on-spring analyses using non-linear $p-y$ curves and the measured slope displacements as loading to the model pile correctly replicated the relative soil and pile movements, and gave a reasonable match to the measured pile displacement and bending behaviour. In design, elastic analysis together with a simple imposed displacement pattern could be used as a serviceability check on pile movements and bending moments; it is unlikely that the full lateral resistance of the soil around the pile will ever be developed in an infrastructure slope, below the top few metres of soil, since a plastic hinge is likely to develop in the pile first. 


\section{ACKNOWLEDGEMENTS}

Design and build contractor for the remedial works at Hildenborough was Cementation Foundations Skanska/Mott MacDonald Ltd. Cementation Foundations Skanska provided the funds to install the instrumentation, and particular thanks go to Tim Fitch, who made this possible. Madeline Penn, Ian Barr, Neil Atkinson and Harvey Skinner all provided invaluable assistance on site. Particular thanks go to Tony O'Brien, Ed Ellis and Graham Birch, who at various stages have reviewed the monitoring data and the draft paper and provided many helpful comments and insights. Laing Rail and Network Rail assisted with post construction site access.

\section{APPENDIX. CALCULATION OF THE CRACKING MOMENT $M_{\text {cr }}$}

The cracking moment of the pile, $M_{\mathrm{cr}}$, is the moment corresponding to the maximum tensile stress that the concrete can accommodate, based on the modulus of rupture of concrete, $f_{\mathrm{r}}$. The relationship between the cracking moment and the modulus of rupture is

$$
M_{\mathrm{cr}}=\frac{f_{\mathrm{r}} I}{y_{\mathrm{t}}}
$$

where $I$ is the second moment of area of the concrete pile section, and $y_{\mathrm{t}}$ is the distance from the centroid to the edge of the section. Relationships between the modulus of rupture of the concrete and the cylinder compressive strength $f_{\mathrm{c}}^{\prime}$ are given by equation (5) (ACI, 1992) and equation (6) (Raphael, 1984). The cylinder strength $f_{\mathrm{c}}^{\prime}$ is usually taken as $0.8 \times f_{\mathrm{cu}}$, where $f_{\mathrm{cu}}$ is the $100 \mathrm{~mm}$ cube compressive strength (British Standards Institution, 1985).

$$
f_{\mathrm{r}}=0.623 \sqrt{f_{\mathrm{c}}^{\prime}}
$$

(where $f_{\mathrm{r}}$ and $f_{\mathrm{c}}^{\prime}$ are in $\mathrm{MPa}$ )

$$
f_{\mathrm{r}}=2 \cdot 3 f_{c}^{\prime 2 / 3}
$$

(where $f_{\mathrm{r}}$ and $f_{\mathrm{c}}^{\prime}$ are in $\mathrm{lbf} / \mathrm{in}^{2}$ ).

The concrete used in the piles was designed to have a minimum cube strength of $35 \mathrm{MPa}$, giving $M_{\mathrm{cr}}=69.9 \mathrm{kN} \mathrm{m}$ for $f_{\mathrm{r}}$ calculated from equation (2), and $M_{\mathrm{cr}}=85.6 \mathrm{kNm}$ for $f_{\mathrm{r}}$ calculated from equation (3). The lines plotted in Fig. 13(a) are the average of the above values $\left(M_{\mathrm{cr}}=77.8 \mathrm{kNm}\right)$. This may, however, be an underestimate of $M_{\mathrm{cr}}$, because the actual cube strength would have been larger than the minimum of $35 \mathrm{MPa}$ specified.

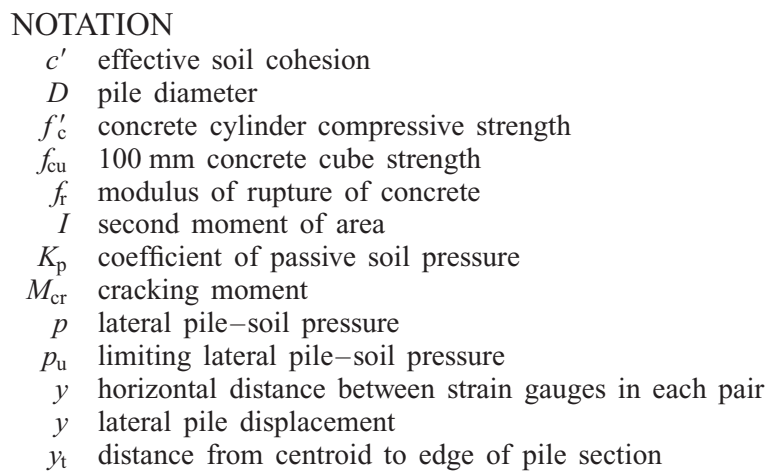

$\gamma$ unit weight of soil

$\varepsilon \quad$ strain

$\varepsilon_{50}$ strain occurring at half maximum stress of undrained triaxial compression test

$\sigma_{\mathrm{v}}^{\prime} \quad$ vertical effective stress

$\sigma_{\mathrm{h}}^{\prime}$ horizontal effective stress

$\phi^{\prime}$ frictional soil resistance

\section{REFERENCES}

American Concrete Institute (ACI) (1992). Causes, evaluations and repair of cracks in concrete structures, ACI 318/318R-89. Detroit, MI: ACI.

American Petroleum Institute (API) (1984). Recommended practice for planning, designing, and constructing fixed offshore platforms, Code RP2A. American Petroleum Institute, Dallas, Texas.

Bakoss, S. L., Burfitt, A. J. \& Cridland, L. (1977). Measurement of strains in concrete members with vibrating wire strain gauges. Australian Road Research 7, No. 3, 21-26.

British Standards Institution (1985). Structural Use of Concrete. London: BSI, BS 8110.

Broms, B. B. (1964). Lateral resistance of piles in cohesionless soils. J. Soil Mech. Found. Engng Div. ASCE 90, No. SM3, $123-156$.

Chen, C. Y. \& Martin, G. R. (2002). Soil structure interaction for landslide stabilising piles. Comput. Geotech. 15, No. 5, 363-386.

Chen, L. T. \& Poulos. H. G. (1997). Piles subjected to lateral soil movements. J. Geotech. Geoenviron. Engng 123, No. 9, 802811.

Clark, J. \& Richards, D. J. (2005). Measurement of bending moment in concrete. Proc. 16th Int. Conf. Soil Mech. Geotech. Engng, Osaka 2, 1027-1030.

Fleming, W. G. K., Weltman, A. J., Randolph, M. F. \& Elson, W. K. (1985). Piling engineering. Bishopbriggs: Blackie \& Son.

Gallois, R. W. \& Edmunds, F. H. (1965). British regional geology: The Wealden District. London: Her Majesty's Stationery Office.

Georgiadis, M., Anagnostopoulos, C. \& Saflekou, S. (1992). Centrifugal testing of laterally loaded piles in sand. Can. Geotech. J. 29, No. 2, 208-216.

Murdock, L. J., Brook, K. M. \& Dewar, J. D. (1991). Concrete materials and practice. London: Edward Arnold.

Oasys (2004). ALP version 18.0 users manual. London: Oasys Ltd.

Raphael, J. M. (1984). Tensile strength of concrete. Am. Conc. Inst. J. 81, No. 2, 158-165.

Skempton, A. W. (1995). Embankments and cuttings on the early railways. Constr. Hist. 11, 33-49.

Sousa Coutinho, A. G. F. (2006). Data reduction of horizontal load full-scale tests on bored concrete piles and pile groups. J. Geotech. Geoenviron. Engng ASCE 132, No. 6, 752-769.

Smethurst, J. A. (2003). The use of discrete piles for infrastructure slope stabilisation. $\mathrm{PhD}$ thesis, University of Southampton.

Squire, J. B. (1880). Earthworks slips in the cuttings and embankments of various railways, with their causes and modes of treatment. Minutes Proc. Instn Civ. Engrs 62, Part 4, 272-287.

Tedd, P., Chard, B. M., Charles, J. A. \& Symonds, I. F. (1984). Behaviour of a propped embedded retaining wall in a stiff clay at Bell Common. Géotechnique 34, No. 4, 513-532.

Wood, L. A. \& Perrin, A. J. (1984). Observations of a strutted diaphragm wall in London Clay: a preliminary assessment. Géotechnique 34, No. 4, 563-579. 